\title{
Resetting the Stress System with a Mifepristone Challenge
}

\author{
Sergiu Dalm ${ }^{1} \cdot$ Adriaan M. Karssen $^{1} \cdot$ Onno C. Meijer ${ }^{1,2} \cdot$ Joseph K. Belanoff ${ }^{3} \cdot$ E. Ronald de Kloet ${ }^{1,2}$
}

Received: 15 July 2018 / Accepted: 18 August 2018 / Published online: 1 September 2018

(C) The Author(s) 2018

\begin{abstract}
Psychotic depression is characterized by elevated circulating cortisol, and high daily doses of the glucocorticoid/progesterone antagonist mifepristone for 1 week are required for significant improvement. Using a rodent model, we find that such high doses of mifepristone are needed because the antagonist is rapidly degraded and poorly penetrates the blood-brain barrier, but seems to facilitate the entry of cortisol. We also report that in male C57BL/6J mice, after a 7-day treatment with a high dose of mifepristone, basal blood corticosterone levels were similar to that of vehicle controls. This is surprising because after the first mifepristone challenge, corticosterone remained elevated for about $16 \mathrm{~h}$, and then decreased towards vehicle control levels at $24 \mathrm{~h}$. At that time, stress-induced corticosterone levels of the 1xMIF were sevenfold higher than the 7xMIF group, the latter response being twofold lower than controls. The 1xMIF mice showed behavioral hyperactivity during exploration of the circular hole board, while the 7xMIF mice rather engaged in serial search patterns. To explain this rapid reset of corticosterone secretion upon recurrent mifepristone administration, we suggest the following: (i) A rebound glucocorticoid feedback after cessation of mifepristone treatment. (ii) Glucocorticoid agonism in transrepression and recruitment of cell-specific coregulator cocktails. (iii) A more prominent role of brain MR function in control of stress circuit activity. An overview table of neuroendocrine MIF effects is provided. The data are of interest for understanding the mechanistic underpinning of stress system reset as treatment strategy for stress-related diseases.
\end{abstract}

Keywords Stress $\cdot$ Brain $\cdot$ Behavior $\cdot$ RU38486 $\cdot$ Glucocorticoid receptor $\cdot$ Mineralocorticoid receptor

\section{Introduction}

Patients suffering from psychotic major depression benefit from a brief treatment with the glucocorticoid/progesterone receptor antagonist RU38486 or mifepristone (MIF), in a dose range of 600-1200 mg/day, once a day for four to seven days. This high dose of the antiglucocorticoid rapidly improves emotional expressions and cognitive abilities, and

Sergiu Dalm and Adriaan M. Karssen have contributed equally to this work.

E. Ronald de Kloet

e.kloet@lacdr.leidenuniv.nl; erdekloet@gmail.com

1 Division of Medical Pharmacology, Leiden/Amsterdam Center for Drug Research and Leiden University Medical Center, Leiden University, P.O. Box 9502, 2300 RA Leiden, The Netherlands

2 Department of Medicine, Division of Endocrinology, Leiden University Medical Center, Room C-7-44, Postal zone C7-Q, PO Box 9600, Leiden, The Netherlands

3 Corcept Therapeutics, Menlo Park, CA, USA restores aberrant levels of the corticosteroids (Murphy et al. 1993; Belanoff et al. 2001, 2002; DeBattista and Belanoff 2006; Flores et al. 2006; Blasey et al. 2009, 2011; Block et al. 2018), see for meta-analysis (Garner et al. 2016). The fast amelioration of psychotic and depressive symptoms is thought to be at least in part due to restoration of glucocorticoid action to which the untreated patient with psychotic depression is resistant, while the anti-progestin activity of MIF is not implicated (Belanoff et al. 2001; Thomson and Craighead 2008). A recent analysis of all controlled phase 2 and 3 studies (MIF: $n=833$ and placebo: $n=627$ ) suggested that a dose of $1200 \mathrm{mg} \mathrm{MIF/day} \mathrm{for} 7$ days significantly reduced psychotic symptoms. For an effective treatment, circulating plasma levels of $\geq 1637 \mathrm{ng} \mathrm{MIF} / \mathrm{ml}$ blood appeared required, while under such conditions basal HPA-axis activity was increased (Block et al. 2017, 2018). The data raise the question how MIF can exert this rapid effect on psychotic major depression.

In the current study, we will address this question from the perspective of adjustment in setpoint of stress system activity by the antiglucocorticoid (Ratka et al. 1988; Hu 
et al. 2012). Previous studies have shown that the effect of MIF on the HPA axis is dependent on the dose, route, and daily frequency of administration. In addition, a more prominent role of the brain mineralocorticoid receptors (MRs) after blockade of GR is likely, while also extrahypothalamic circuits are involved. Table 1 presents the published MIF effects on the HPA axis, which can be summarized as follows.

First, a central action of MIF is likely, since more than 100,000 -fold lower dose centrally (10-100 ng local and i.c.v.) than systemically (10-200 $\mathrm{mg}$ s.c. $/ \mathrm{kg}$ rat) could achieve feedback blockade in behaviorally active fashion (de Kloet et al. 1988; Ratka et al. 1989; van Haarst et al. 1997; Dalm et al. 2008). In spite of rapid degradation and poor brain penetration, such doses of MIF in the $10-200 \mathrm{mg}$ range can enter the brain and do translocate the immunoreactive (ir) glucocorticoid receptor (GR) to the neuronal nuclei (Van Eekelen et al. 1987; de Kloet 1991). This finding was confirmed and further extended by the association of the MIF-GR complex to hippocampal Glucocorticoid Response Elements (GRE's) (Spiga et al. 2011). ${ }^{3} \mathrm{H}-\mathrm{MIF}$ was found to bind to glucocorticoid receptor sites in human brain slices in vitro (Sarrieau et al. 1986).

Second, the prolonged and profound increase in secretion of corticosterone was the expected outcome of MIF interference with the stress-induced GR-mediated negative feedback (Ratka et al. 1989). The low GR occupancy during basal trough conditions explains the lack of acute MIF effects, but the antagonist can block during the p.m. phase or after minor stressors provided corticosterone levels are increased (Reul and de Kloet 1985).

Third, following MIF, the initial stress-induced rise in HPA-axis activity was attenuated. This blunted HPA-axis response likely was due to activation of co-localized hippocampal MRs. These MRs mediate rapid actions of corticosterone that precede those of GRs (de Kloet 1991; Joëls and de Kloet 1992; Karst et al. 2005; Joëls 2006). Indeed, central (hippocampal) MR blockade disinhibited the HPAaxis activity in rodents (Ratka et al. 1989; Oitzl et al. 1995; van Haarst et al. 1997) and humans (Dodt et al. 1993; Young et al. 1998; Deuschle et al. 1998).

Fourth, repeated daily administration for 5 days up to three weeks revealed an unexpected apparent GR agonism of MIF and blocked basal and stress-induced HPA-axis activity in rodents (Havel et al. 1996; Wulsin et al. 2010; van der Veen et al. 2013). Similar GR agonism rather than antagonism was noted with the novel selective GR modulators C-108297, C-125281, and the GR modulator/MR antagonist C-118335 (Solomon et al. 2014; Nguyen et al. 2017; Kroon et al. 2018; Van den Heuvel et al. 2016). Repeated MIF treatment caused a differential pattern of activation and inhibition of central inputs to the PVN, as judged from c-FOS activation (Wulsin et al. 2010).
Fifth, continuous infusion of $100 \mathrm{ng} \mathrm{MIF/hr} \mathrm{i.c.v.} \mathrm{for} 3$ days enhanced stress-induced corticosterone secretion and increased the circadian amplitude of basal corticosterone level (Van Haarst et al. 1996; van Haarst et al. 1997). Continuous i.c.v. infusion improved spatial memory, which was impaired, however, when MIF was administered daily as a bolus of $100 \mathrm{ng} / \mathrm{rat}$ i.c.v. immediate before or after the learning trial (Oitzl and de Kloet 1992; Oitzl et al. 1998). The findings reinforce the notion of temporal and contextual diversity in glucocorticoid actions in various brain regions (Joëls and de Kloet 1992; Joëls et al. 2018).

Finally, twice rather than once a day MIF enhanced HPA-axis activity in diabetic rats (Revsin et al. 2009; Stranahan et al. 2008) and, if applied at the end of three weeks daily stress exposure, blocked the reduction in neurogenesis (Oomen et al. 2007; Mayer et al. 2006); even a single day treatment on day 18 was effective in this paradigm (Hu et al. 2012). MIF administered twice a day, at postnatal days 26-28, normalized deficits in hippocampal-dependent cognitive functions and associated neuronal activity that were previously induced by early-life maternal deprivation of rats (Arp et al. 2016; Loi et al. 2017).

A striking aspect of MIF's efficacy is the ability to reset the stress system. This phenomenon was previously observed when the adrenals were rapidly (within 30 s under anesthesia) removed immediately following a severe stress to prevent the surge in glucocorticoid secretion. We noted a long-lasting ( $>1$ week) and profound potentiation in morphine- or $\beta$-endorphin-induced analgesia, which was correlated with increased opioid receptor binding and decreased hippocampal enkephalin and dynorphin mRNA expression. The antinociceptive effect of morphine was normalized if corticosterone was administered at the time of adrenalectomy (ADX) to mimic the stress or circadian rise. Also, $100 \mathrm{ng}$ MIF i.c.v. administered during the p.m. circadian rise at $1 \mathrm{~h}$ prior to ADX caused long-term sensitization to morphine, apparently because the impact of the high prestress corticosterone in brain was antagonized (Ratka et al. 1988; Iglesias et al. 1991).

In the present study, we mimicked in mice the high-dose regimen of MIF that was beneficial in the patient studies (Block et al. 2018). For this purpose, we applied a noninvasive stress-free method for steroid delivery via oats (Dalm et al. 2008). After the first (1xMIF) and the seventh administration (7xMIF) we assessed (i) the circadian corticosterone secretion pattern; (ii) the behavioral and corticosterone response to novelty during exploration of a circular hole board at $24 \mathrm{~h}$ post-treatment. Hippocampal and hypothalamic MR, GR, and CRH mRNA expressions were also measured. Then, we investigated metabolism and brain penetration of MIF using Liquid chromatography-Mass Spectrometry-Mass Spectrometry (LC/MS/MS). Monolayers of pig kidney epithelial cells (LLC-PK1) stably expressing 


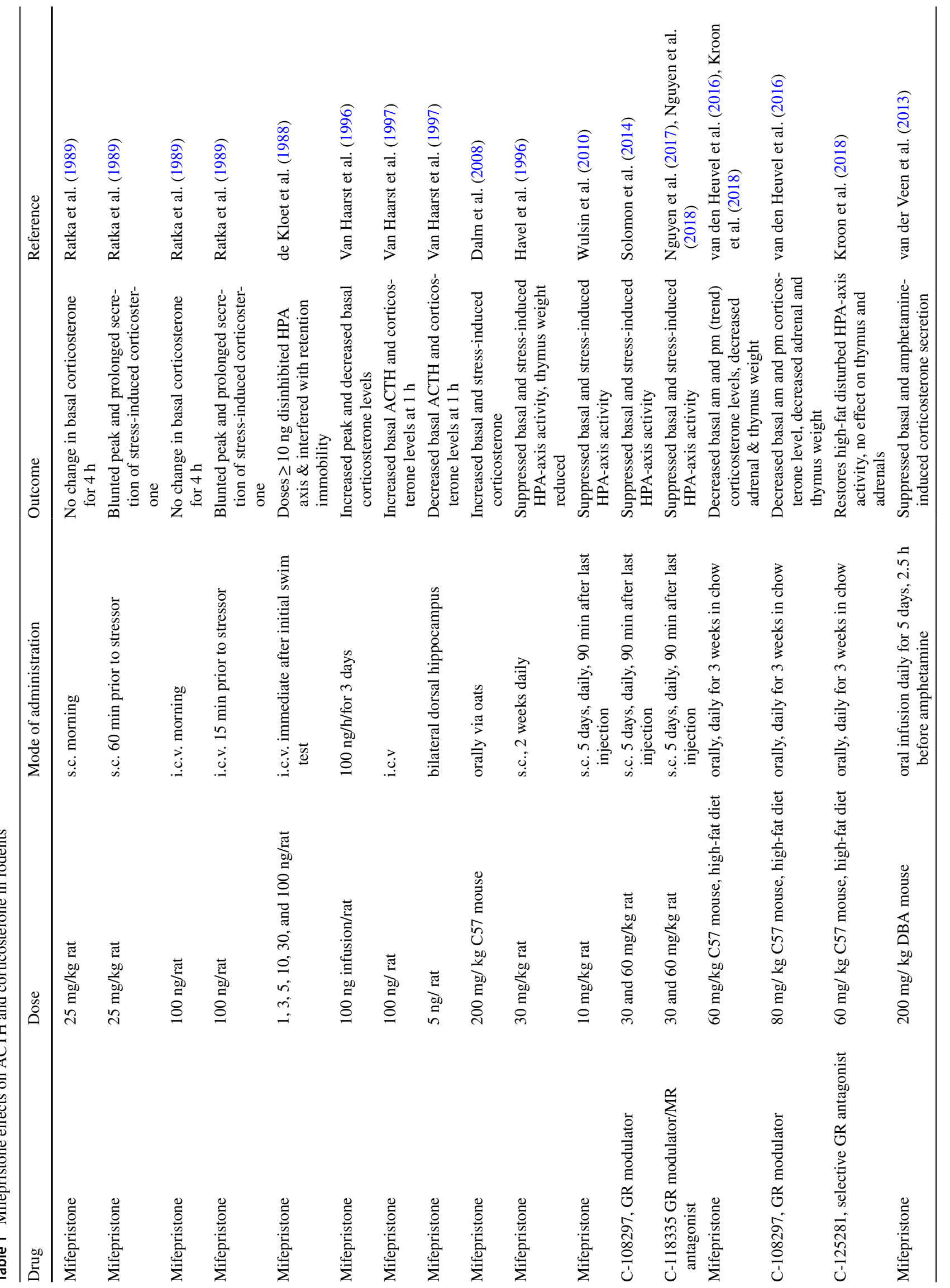


human multidrug-resistance P-glycoprotein (MDR1 Pgp) were used to examine the effect of MIF on cortisol transport (Karssen et al. 2001). We conclude with a discussion on the role of limbic-mesocortical circuits beyond HPA-axis regulation in prediction of treatment response to MIF.

\section{Methods}

\section{Animals}

Male C57BL/6J mice, 8-10 weeks of age, were purchased from Janvier (France). Upon arrival at the animal facilities (Gorlaeus Laboratory, LACDR, University of Leiden, The Netherlands), mice were single housed in a temperature $\left(21 \pm 1{ }^{\circ} \mathrm{C}\right)$ and humidity $(55 \pm 5 \%)$-controlled room, with food and water ad libitum; for ten days before the start of the experiment (12-12-h light/dark cycle; lights on 0700-1900 h). During this period, mice were weighed and handled every other day. Experiments were approved by the Local Committee for Animal Health, Ethics and Research of the University of Leiden. Animal care was conducted in accordance with the European Union Directive 2010/63/EU.

\section{Study Design}

The experiments were conducted with separate groups of mice. We measured (1) the 24-h circadian corticosterone secretion, following single and repeated administration of MIF (200 mg/kg; 1x/day for seven days). In addition, we collected blood samples around the time of the circadian corticosterone peak $32 \mathrm{~h}$ after the last administration of MIF. (2) Exploration behavior was measured in a circular hole board. Corticosterone concentrations were analyzed before (basal) and after exposure to the circular hole. (3) Following behavioral testing, mice were decapitated and brains were prepared for measuring the expression levels of MR, GR, and CRH mRNA in the hippocampus and paraventricular nucleus of the hypothalamus (PVN).

\section{Procedures}

Familiarization of mice to oat administration and drug delivery procedures as described in (Dalm et al. 2008) are applicable to all experiments of this study.

\section{Familiarization to Oat Administration}

One week prior to the start of the experiment, a feeding cup $(2.3 \mathrm{~cm}$ diameter $\times 2.5 \mathrm{~cm}$ high) was taped to the floor in a corner of the home cage, opposite the nest location. For familiarization, three flakes of oats (Speltvlokken, Biologische teelt, Graanpletterij de Halm, Netherlands; $\pm 140 \mathrm{mg}$ ) 
were placed in the cup on three consecutive days every other day, $2 \mathrm{~h}$ after lights on. The top of the home cage was lifted and the sawdust was removed from the cup using an air puff generated with a pipette. Next, the oats were placed into the cup using forceps to minimize human odor transfer. Thereafter, the home cage was closed and the mouse was allowed to eat the oats undisturbed. All the oats were consumed within $10 \mathrm{~min}$.

\section{Drug Delivery}

Preparation of drug delivery via oats: One day prior to the experiment three flakes of oats were placed in a glass vial and the solutions containing GR antagonist or dissolvent (VEH) were applied. The glass vials containing the oats were kept at room temperature over night. Within $16 \mathrm{~h}$, the solution was absorbed by the oats and they were dry when presented to the mice.

MIF (kindly provided by Corcept Therapeutics, Menlo Park, CA, U.S.A.) was dissolved in $1 \mathrm{ml} 0.9 \% \mathrm{NaCl}$ containing $0.25 \%$ carboxymethylcellulose and $0.2 \%$ Tween 20 $(\mathrm{VEH}=$ dissolvent). From this solution, $50 \mu \mathrm{l}$ was applied to the oats (mice received a dose of $200 \mathrm{mg} / \mathrm{kg}$ MIF).

\section{Hormone Assays}

The circadian corticosterone concentrations were measured in blood samples obtained via tail incision (Dalm et al. 2005). Briefly, a small incision with a razor blade at the base of the tail allowed collection of $50 \mu$ blood within $90 \mathrm{~s}$ after opening of the animal's cage. Following decapitation, trunk blood was collected individually in capillaries coated with potassium-EDTA (Sarstedt, Germany), stored on ice, and centrifuged with $13,000 \mathrm{rpm}$ at $4{ }^{\circ} \mathrm{C}$ for $10 \mathrm{~min}$. Plasma was stored at $-20^{\circ} \mathrm{C}$. Corticosterone concentrations were measured using commercially available radio immunoassay kits ${ }^{125}$ I-corticosterone (MP Biomedicals, Inc., NY, USA; sensitivity $3 \mathrm{ng} / \mathrm{ml})$.

\section{Experiment 1: Effect of GR Antagonism on Corticosterone Secretion}

\section{Animals}

Mice $(N=54)$ were randomly assigned to three treatment groups ( $N=18$ per group): (1) single mifepristone ( $1 \mathrm{xMIF})$; (2) mifepristone once a day on seven consecutive days (7xMIF); or (3) VEH on seven consecutive days (VEH). Oats + MIF or Oats + VEH were placed in the feeding cup at $0900 \mathrm{~h}$, and consumed within $10 \mathrm{~min}$.

\section{Experimental Design}

The circadian corticosterone secretion was determined in blood samples collected via tail incision every two hour over a period of $24 \mathrm{~h}$. The first blood sample was taken at $1100 \mathrm{~h}$, i.e., two hours after MIF or VEH was administrated, and the last at $0900 \mathrm{~h}$ the next day. Subsequent blood samples were collected starting $32 \mathrm{~h}$ after the last administration around the circadian corticosterone peak at 1700, 1900, 2100, and $2300 \mathrm{~h}$.

The three treatment groups (each $N=18$ ) were divided in three subgroups each, consisting of six mice. Thus, from each mouse, one blood sample was taken every six hours and each time point consisted of six mice per group. During the dark period, blood sampling took place under red light conditions.

\section{Experiment 2: Corticosterone and Behavioral Responses to the Circular Hole Board}

\section{Animals}

Mice $(N=24)$ were randomly assigned to three treatment groups ( $N=8$ per group): (1) single mifepristone (1xMIF); (2) mifepristone once a day on seven consecutive days (7xMIF) or (3) VEH on seven consecutive days (VEH). Oats + MIF or Oats + VEH were placed in the feeding cup at $0900 \mathrm{~h}$, and consumed within $10 \mathrm{~min}$.

\section{Experimental Design}

Twenty-four hours after the last administration of MIF or VEH, we took a blood sample via tail incision, and placed the mouse for five min on the circular hole board; the behavioral response was analyzed. Immediately following behavioral testing, mice were decapitated. Corticosterone concentrations were determined in trunk blood. Brains were snap frozen in isopentane, pre-cooled on dry ice/ethanol, and stored at $-80{ }^{\circ} \mathrm{C}$ until further use, i.e., to determine, MR, GR, and CRH mRNA expression levels in brain tissue. Thymus and adrenals were removed and weighed.

\section{Circular Hole Board}

Apparatus A gray round plate (Plexiglass; $110 \mathrm{~cm}$ diameter) with 12 holes ( $5 \mathrm{~cm}$ diameter, $5 \mathrm{~cm}$ deep) at equal distances from each other, and at a distance of $10 \mathrm{~cm}$ from the rim of the hole to the rim of the plate, was situated one meter above the floor in a different experimental room than the housing room. Light conditions on the surface of the board were $120 \mathrm{~lx}$. To minimize and distribute odor cues, the surface was cleaned with $1 \% \mathrm{HAc}$ and the board was turned 
(randomly clockwise and anticlockwise) before a mouse was tested. Behavior was recorded on videotape and analyzed with an automated tracking system (EthoVision 3.1, Noldus Information Technology, Wageningen, The Netherlands). The position of the mouse was sampled five times per second. To calculate the distance walked, we set the minimal distance between samples to $3 \mathrm{~cm}$. The following parameters related to general activity, exploratory strategies, and possible anxiety-related behaviors were analyzed: distance walked ( $\mathrm{m}$ ) on the board and in specified zones: start center was defined as a circle of $30 \mathrm{~cm}$ diameter and the rim zone: a ring of $4.5 \mathrm{~cm}$ at the outer perimeter of the plate. Parameters: velocity $(\mathrm{cm} / \mathrm{s})$, number of holes visited; sequence of hole visits (serial: more than two holes in sequence; perseveration: repeatedly visiting the same hole or alternately visiting two neighboring holes); latency (s) to leave the center; latency (s) to and time spent (s) in rim zone.

\section{In Situ Hybridization for MR, GR, and CRH mRNA}

Brains were sectioned at $-20{ }^{\circ} \mathrm{C}$ in a cryostat microtome at $10 \mu \mathrm{m}$ in the coronal plane through the level of the PVN and dorsal hippocampus. Sections were thaw-mounted on poly-L-lysine-coated slides $(0.001 \%)$, air dried, and kept at $-80{ }^{\circ} \mathrm{C}$ until further use.

In situ hybridizations using ${ }^{35} \mathrm{~S}$-labeled ribonucleotide probes (MR, GR, CRH) were performed as described previously (Schmidt et al. 2009). Briefly, sections were fixed in $4 \%$ paraformaldehyde and acetylated in $0.25 \%$ acetic anhydride in $0.1 \mathrm{M}$ triethanolamine $/ \mathrm{HCl}$. Subsequently, brain sections were dehydrated in increasing concentrations of ethanol. The antisense RNA probes were transcribed from linearized plasmids containing exon- 2 of mouse MR and $\mathrm{GR}$, and the full length coding regions of $\mathrm{CRH}$ (rat). Tissue sections (3-4 per slide) were saturated with $100 \mu$ l hybridization buffer containing $20 \mathrm{mM}$ Tris- $\mathrm{HCl}$ ( $\mathrm{pH} \mathrm{7.4),} \mathrm{50 \%}$ formamide, $300 \mathrm{mM} \mathrm{NaCl}, 1 \mathrm{mM}$ EDTA (pH 8.0), 1x Denhardt's, $250 \mu \mathrm{g} / \mathrm{ml}$ yeast transfer RNA, $250 \mu \mathrm{l} / \mathrm{ml}$ total RNA, $10 \mathrm{mg} / \mathrm{ml}$ salmon sperm DNA, $10 \%$ dextran sulfate, $100 \mathrm{mM}$ dithiothreitol, $0.1 \%$ SDS, $0.1 \%$ sodium thiosulfate, and supplemented with approximately $1.5 \times 10^{6} \mathrm{cpm}{ }^{35} \mathrm{~S}$-labeled riboprobe. Brain sections were cover-slipped and incubated overnight at $55{ }^{\circ} \mathrm{C}$. The next day sections were rinsed in 2xSSC, treated with RNaseA $(20 \mathrm{mg} / \mathrm{ml})$, and washed in increasingly stringent SSC solutions at room temperature. Finally, sections were washed in $0.1 \times \mathrm{xSC}$ at $65{ }^{\circ} \mathrm{C}$ for $30 \mathrm{~min}$ and dehydrated through increasing concentrations of ethanol. All age groups were assayed together. Films were opposed to Kodak Biomax MR film (Eastman Kodak Co., Rochester, NY) and developed.

Autoradiographs were digitized, and optical density of the areas of interest was quantified using image analysis computer software (analySIS 3.1, Soft Imaging System GmbH).
The average density of six measurements for each animal was calculated.

\section{Statistics}

Data are presented as mean \pm SEM. The circadian profile of corticosterone was analyzed by analysis of variance (ANOVA) (factor: treatment) with repeated measurements, followed by Fisher's Least Significant Difference (LSD) post hoc test. Total corticosterone (AUC: area under the curve) over $24 \mathrm{~h}$ was calculated for light and dark periods of $12 \mathrm{~h}$, subjected to ANOVA, with treatment and time of the day as fixed factors. Statistical analysis was similar as for corticosterone. Body, adrenal, and thymus weights were analyzed using one-way ANOVA followed by Bonferroni's multiple comparison post hoc test. Statistical significance was accepted at $p<.05$.

\section{Experiment 3: Metabolism and Membrane Transport of Mifepristone}

Young adult male Wistar rats (Charles River, Germany) were housed under a 12/12-h light/dark cycle with lights on at 7:00 $\mathrm{h}$ in separate temperature $\left(21^{\circ} \mathrm{C}\right)$ - and humiditycontrolled rooms. Food and drinking water were available $\mathrm{ad}$ libitum. Before and during experiments, rats were handled daily. Experiments were approved by the Local Committee for Animal Health, Ethics and Research of the University of Leiden. Animal care was conducted in accordance with the European Union Directive 2010/63/EU.

Rats were treated with MIF for five days. Body weight was monitored throughout this period. MIF suspended in an aqueous solution containing $0.25 \%$ carboxymethylcellulose $/ 0.2 \%$ Tween 20 was administered by gavage at a dose of $50 \mathrm{mg} / \mathrm{kg}$ once a day. Groups treated with vehicle were also included in all experiments. On the last day, 1.5 or $3 \mathrm{~h}$ after the last injection, the animals were killed by decapitation at the end of the day during the circadian rise of corticosterone levels. Brain and plasma were collected and frozen until further use. Adrenals and thymus were also dissected and weighed. Plasma levels of corticosterone were determined using a ${ }^{125}$ I-corticosterone radioimmunoassay (MP Biomedicals, Costa Mesa, CA).

\section{Corticosteroid Determination in Brain and Plasma}

Using Liquid Chromatography-Mass Spectrometry-Mass Spectrometry (LC/MS/MS), steroid profiles were made of samples of the rat cortex and plasma. We measured levels of corticosterone, mifepristone (17 $\beta$-hydroxy-11 $\beta$-(4-dimethylaminophenyl)$17 \alpha$-(1-propynyl)estra-4,9-dien-3-one), and its three main metabolites, the mono-demethylated (RU42633, 
$17 \beta$-hydroxy-11 $\beta$-(4-monomethylaminophenyl)-17 $\alpha$ (1-propynyl)estra-4,9-dien-3-one), the didemethylated (RU42848, 17 $\beta$-hydroxy-11 $\beta$-(4-aminophenyl)-17 $\alpha$-(1propynyl)estra-4,9-dien-3-one), and the hydroxylated

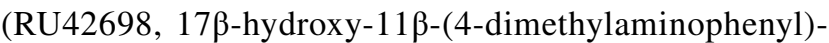
$17 \alpha$-(1-propynol)estra-4,9-dien-3-one) (Deraedt et al. 1985). Samples were prepared for assay by dichloromethane/ethanol extraction essentially as previously described (Karssen et al. 2001).

The LC/MS/MS assays were performed on a Triple Stage Quadrupole mass spectrometer (Thermo Finnigan TSQ Quantum, San Jose, CA, USA) with an atmospheric pressure chemical ionization interface. A modification of the method of (van der Hoeven et al. 1997) was used. The analysis was performed in positive ionization mode using selective reaction monitoring of MIF, its three main metabolites, corticosterone, and dexamethasone. The $[\mathrm{M}+\mathrm{H}]^{+}$ precursor ions were fragmented using argon as collision gas. The $\mathrm{m} / \mathrm{z}$ ratios of the most abundant product ions were alternately scanned. The ion source temperature and the nebulization heater were kept at $200{ }^{\circ} \mathrm{C}$ and $400{ }^{\circ} \mathrm{C}$, respectively. The voltages on the corona needle and on the electron multiplier were set at $10 \mu \mathrm{A}$. Each experiment, a new standard series was made in $25 \%$ methanol with concentrations ranging from 1 to $500 \mathrm{ng} / \mathrm{ml}$ of all steroids. Dexamethasone $(1 \mu \mathrm{g} / \mathrm{ml})$ was used as an internal standard. A Surveyor LC System (Thermo Finnigan) was used to inject $20 \mu \mathrm{l}$ of the standard or extraction samples. A gradient of methanol-water (containing $1 \mathrm{~g} / \mathrm{l}$ acetic acid) changing from $50 / 50 \%$ to $90 / 10 \%$ at a flow rate of $500 \mu \mathrm{l} /$ min separated the steroids on an $\mathrm{ADS} \mathrm{C}_{18}$ column. All samples were measured in duplo. The detection limit of this assay was $1-5 \mathrm{ng} / \mathrm{ml}$ for each steroid.

Steroid concentrations were calculated from a standard plot of area under the curve versus concentration. The standard curves usually displayed an $\mathrm{r}^{2}$ of more than 0.95 . Presented data are corrected for recovery of dexamethasone, which was in the order of $25-50 \%$.

\section{Transepithelial Transport and Inhibition Studies}

In order to examine the inhibitory action of MIF on Pgpmediated cortisol transport, we used monolayers of the porcine kidney epithelial cell-line LLC-PK1, and LLC-PK1 cells stably transfected with cDNA of the human MDR1 gene encoding P-glycoprotein (LLC-PK1:MDR1) as previously described (Karssen et al. 2001). Cells obtained from the American Type Culture Collection (Manassas, VA) were kindly provided by the Dutch Cancer Institute (Amsterdam, The Netherlands) (Schinkel et al. 1995). MIF was added at a final concentration of 10 or $100 \mu \mathrm{M}$ one hour before the addition of ${ }^{3} \mathrm{H}$-cortisol (Amersham Pharmacia Biotech, UK; specific activity $63 \mathrm{Ci} / \mathrm{mmol}$ ) at a final concentration of $15 \mathrm{nM}$. In a separate experiment, a mix of MIF and metabolites at therapeutically relevant concentrations was added.

\section{In Vivo Cortisol Uptake in Brain: Effect of MIF Pretreatment}

To examine the in vivo effect of MIF on cortisol uptake into the brain, we have treated rats orally with $100 \mathrm{mg} / \mathrm{kg}$ MIF or vehicle $(0.25 \%$ carboxymethylcellulose $/ 0.2 \%$ Tween 20$)$ $(N=7)$ each morning for 4 days. On the last day, all animals received a tracer dose of ${ }^{3} \mathrm{H}$-cortisol by s.c. injection $45 \mathrm{~min}$ after the last MIF treatment. After another $45 \mathrm{~min}$, animals were decapitated. Trunk blood was collected and brain and liver were dissected. Tissue was weighed and solubilized in Soluene-350. Together with $100 \mu \mathrm{l}$ plasma samples, tissue samples were counted to determine radioactivity.

\section{Statistical Analysis}

Data were evaluated by Student's $t$ test or ANOVA followed by Tukey HSD post hoc test. The results of the monolayer experiments were analyzed by Repeated Measures ANOVA. Significance was taken at $p<.05$.

\section{Results}

\section{Experiment 1: Effect of GR Antagonism on Corticosterone Secretion}

\section{Circadian Pattern of Plasma Corticosterone Level}

Mice of all groups showed a circadian corticosterone rhythm (Fig. 1a; time $F(11,165)=35.051 ; p<.001)$ as previously described (Dalm et al. 2005). The corticosterone secretion of control mice increased from $1500 \mathrm{~h}$ onwards, with peak levels $( \pm 100 \mathrm{ng} / \mathrm{ml})$ at the end of the light phase and the beginning of the dark phase (between 1700 and $2100 \mathrm{~h}$ ). Interestingly, the frequency of MIF administration affected the course of the circadian rhythm (time* group: $F(22$, $165)=15.992 ; p<.001)$. Corticosterone concentrations in 1xMIF-mice were significantly higher from 1100 until $0100 \mathrm{~h}(p<.01)$, reaching and maintaining peak levels from 1300 until $2300 \mathrm{~h}( \pm 300 \mathrm{ng} / \mathrm{ml})$. Around $2300 \mathrm{~h}$, concentrations readily declined until there was no difference in corticosterone concentration at $0300 \mathrm{~h}$ versus control and 7xMIFadministrated mice. There was a sudden significant increase versus controls $(p=.001)$ and 7 XMIF mice $(p=.013)$, at $0500 \mathrm{~h}$. In contrast, repeated MIF administration did not boost the concentrations of corticosterone as was observed for 1xMIF-administrated mice; the time course was similar 

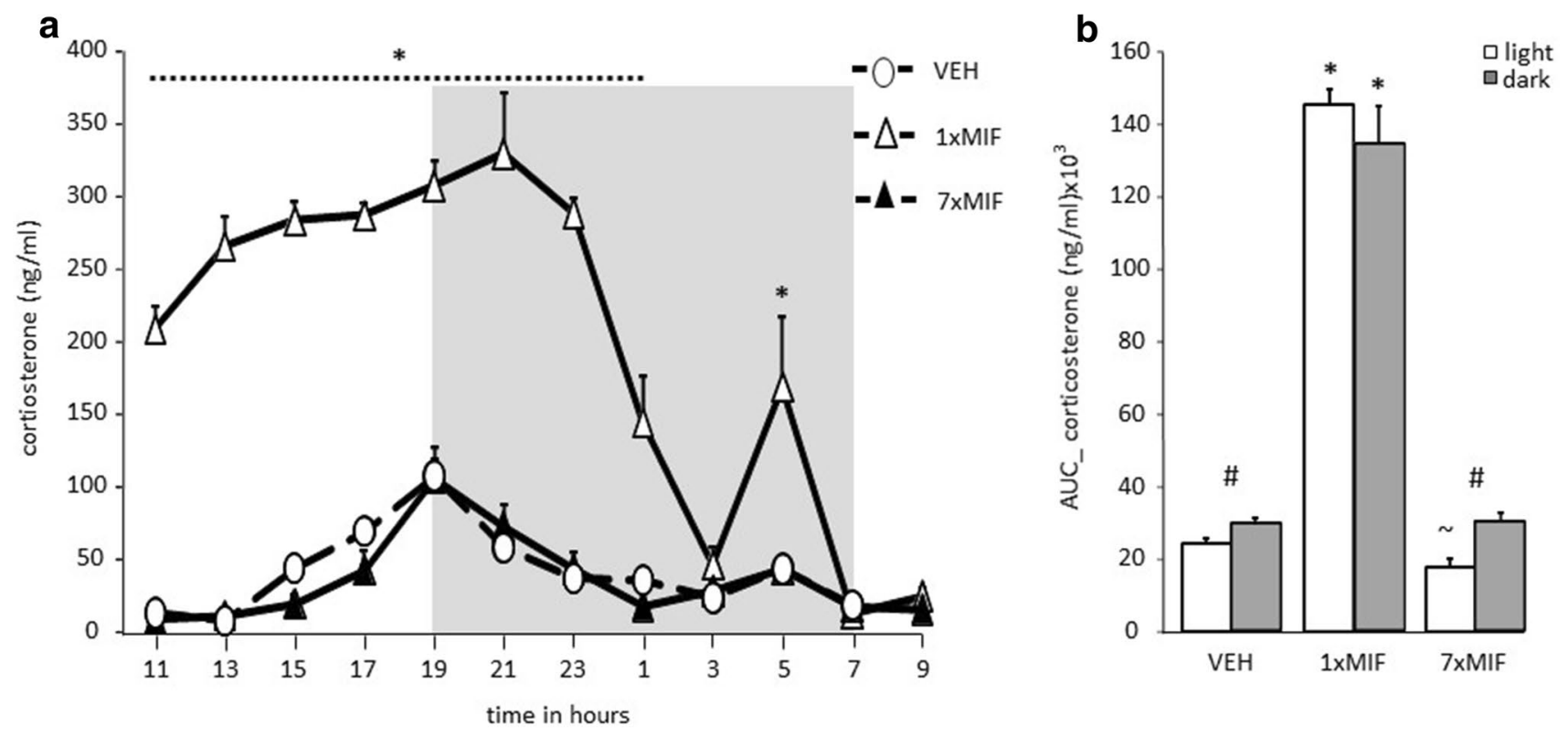

Fig. 1 a Circadian secretion of corticosterone in $\mathrm{ng} / \mathrm{ml}$ measured every $2 \mathrm{~h}$ in blood plasma of male mice C57BL/6J that received RU38486 (MIF) once (1xMIF) or for seven days (7xMIF). Mice were entrained in a 12-12-h light-dark cycle (dark phase from 1900 to $0700 \mathrm{~h}$ represented by the gray-shaded area). b Total corticosterone

to VEH mice. Overall, there was a main effect of treatment due to the high corticosterone concentrations in the $1 \mathrm{xMIF}$ mice $(F(2,15)=550.923 ; p<.001)$.

\section{Total amount corticosterone}

The total amount of corticosterone calculated as area under the curve (AUC) over $24 \mathrm{~h}$ showed a main effect of treatment (Fig. 1b AUC: $F(2,17)=392.094 ; p<.001)$. AUC corticosterone during the dark period $(1900-0700 \mathrm{~h})$ was higher than during the light period $(0700-1900 \mathrm{~h})$ in VEH and 7xMIF mice (paired t-test; both $p<.01$ ). 1xMIF mice had similar high AUC corticosterone levels during the light and dark periods, both significantly higher than VEH and $7 \mathrm{xMIF}$ mice. Interestingly, AUC corticosterone was lowest during the light period of 7 XMIF mice $(p<.039$ versus VEH) due to the low corticosterone concentrations measured from 1500 till $1700 \mathrm{~h}$.

\section{Corticosterone Around the Circadian Peak: $32 \mathrm{~h}$ After Mifepristone Administration}

Treatment effects were found around the time of the circadian peak (Fig. 2, 1700-2300h; $F(2,15)=6.308 ; p=.01$ ). Thirty-two hours after the last administration, 1xMIF mice secretion in $\mathrm{ng} / \mathrm{ml}$ during the light and dark period of the day, determined as area under the curve (AUC); ng/ml. Data are presented as mean \pm SEM; $p<.05 *$ versus other groups, ${ }^{\#}$ within groups, $\sim 7 \mathrm{xMIF}$ versus VEH

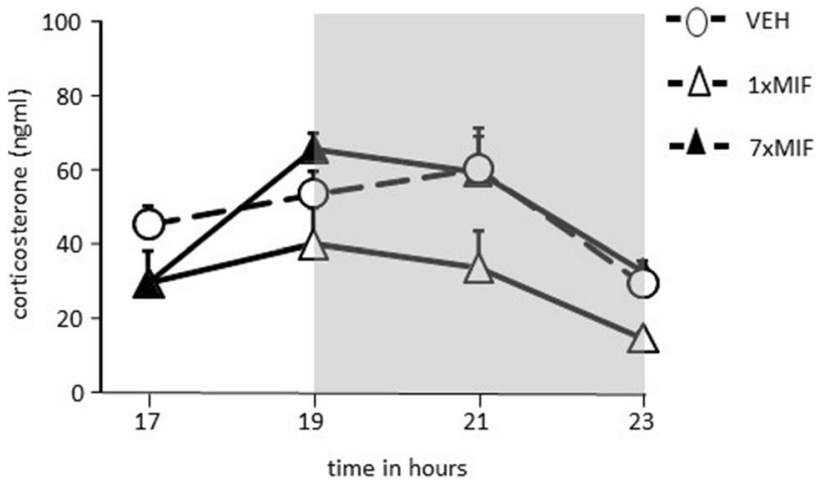

Fig. 2 Corticosterone $(\mathrm{ng} / \mathrm{ml})$ secretion during the circadian peak in mice, $32 \mathrm{~h}$ after last administration of RU38486 (MIF), 1xMIF, $7 \mathrm{xMIF}$, or VEH (dark phase from 1900 to $2300 \mathrm{~h}$ represented by the gray-shaded area). Data are presented as mean \pm SEM

secreted less corticosterone than VEH $(p=.007)$ and 7xMIF mice $(p=.008)$. No statistical difference was found for corticosterone secretion patterns of VEH and 7xMIF groups.

\section{Experiment 2: Corticosterone and Behavioral Responses to the Circular Hole Board}

\section{Basal and Novelty-Induced Corticosterone Secretion}

Basal resting as well as novelty-induced corticosterone were affected $24 \mathrm{~h}$ after the last treatment (Fig. 3; treatment $F(2$, 


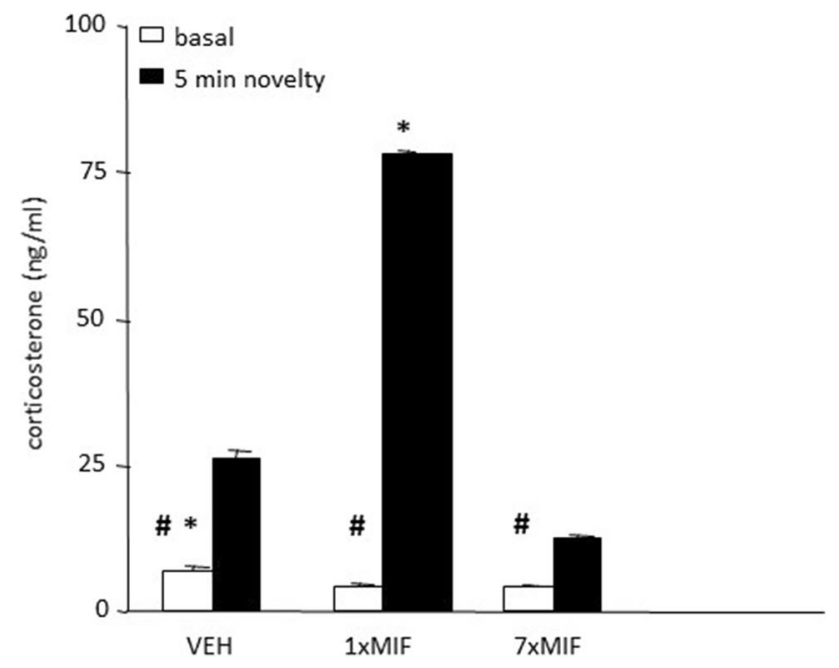

Fig. 3 Basal and novelty (5 min exposure to the circular hole board)induced corticosterone $(\mathrm{ng} / \mathrm{ml})$ were determined in mice, $24 \mathrm{~h}$ after last administration of VEH, 1 xMIF, or 7 XMIF. Data are presented as mean \pm SEM; $p<.05 *$ versus other groups, ${ }^{\text {" within groups }}$

$44)=17.175 ; p<.0001 ;$ time $F(1,44)=45.980 ; p<.0001$; treatment*time $F(2,44)=17.626 ; p<.0001)$. Basal resting corticosterone differed significantly between the groups $(F(2,23)=14.656 ; p<.001)$ and was lower in both MIFtreated groups than in VEH mice $(p<.001)$. Basal corticosterone of $1 \times$ MIF and 7xMIF mice was comparable. After five min on the circular hole board, corticosterone was increased in all groups compared to baseline, however to a different degree $(F(2,23)=19.074 ; p<.0001)$. Corticosterone levels in $1 \times$ MIF were $300 \%$ of the VEH group and $700 \%$ of the $7 \times$ MIF group (both $p<.0001$ ); corticosterone of the VEH group was about twice as high as in the $7 \mathrm{xMIF}$ group $(p<.05)$.

Fig. 4 Expression of MR mRNA, measured as optical density (OD) in the hippocampal subfields dentate gyrus (DG), CA1, CA2, and CA3, $24 \mathrm{~h}$ after last administration of VEH, 1xMIF, or 7xMIF. Data are presented as mean $\pm \mathrm{SEM}$; $p<.05 *$ versus other groups, within groups
Expression of MR, GR, CRH mRNA in Hippocampus and PVN

Hippocampal MR mRNA expression was differentially affected by treatment, $24 \mathrm{~h}$ post-administration, across all subfields (Fig. 4; treatment - DG: $F(2,23)=11.005$; $p=.001 ; \mathrm{CA} 1: F(2,23)=12.887 ; p=.001 ; \mathrm{CA} 2: F(2$, $23)=14.267, p=.001$; CA3: $F(2,23)=11.550 ; p=.001)$. MR mRNA expression was reduced across all subfields in $1 \mathrm{xMIF}$-mice compared to VEH and 7xMIF-mice $(p<.05)$. Repeated MIF administration increased MR mRNA expression in the CA2 specifically versus VEH and 1xMIF-mice ( $p=.016$ and $p=.001$, respectively). Neither GR nor CRH mRNA expression in hippocampus and PVN were affected by treatment (data not shown).

\section{Exploration on the Circular Hole Board}

Twenty-four hours after administration, the behavioral response differed during five min exploration on the circular hole board (Table 2: MANOVA: $F(20,26)=3.772$; $p=.001)$. Following initial slower movement out of the central start position, 1 xMIF mice showed hyperactivity: they walked longer distances, with a faster speed of moving, visited more holes, and made more rim dips (vs. VEH and 7xMIF-mice: $p<.05)$. Interestingly, 7xMIF-mice made more use of a serial search strategy (vs. VEH mice: $p=.05$ ).

\section{Other Physiological Measures}

Treatment did not influence body weight. Adrenal weight ( $F$ $(3,34)=3.733 ; p=.035)$ was highest in both MIF groups, but significantly higher in 7xMIF than in VEH $(p=.005)$ : adrenals in $\mathrm{mg}$, mean $\pm \mathrm{SEM}$ : VEH $23.5 \pm 2.8$; $1 \mathrm{xMIF}$

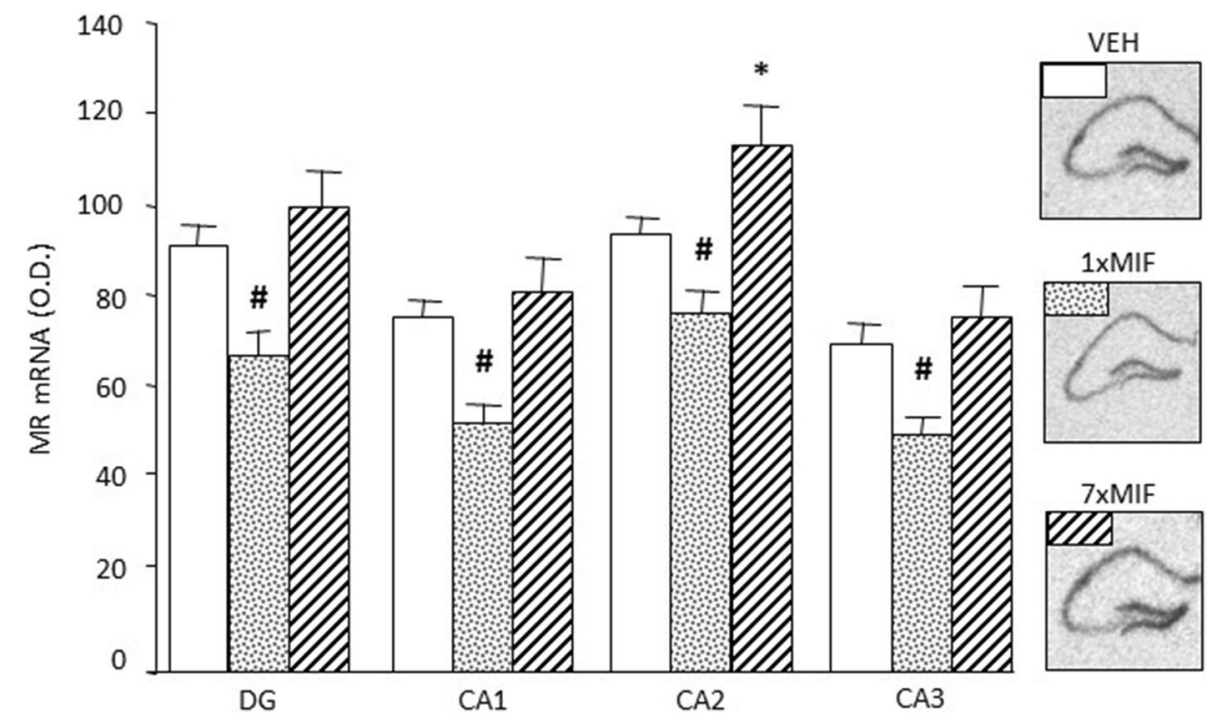


Table 2 The behavioral response during five min circular hole board exposure, $24 \mathrm{~h}$ after the last administration with RU38486 (MIF)

\begin{tabular}{llll}
\hline & VEH & $1 \times$ XIF & $7 \mathrm{xMIF}$ \\
\hline General activity & & & \\
Distance walked (m) & $7.9 \pm 0.7$ & $15.0 \pm 1.9^{*}$ & $7.5 \pm 0.9$ \\
Speed of moving (cm/s) & $8.6 \pm 0.4$ & $11.6 \pm 0.8^{*}$ & $9.9 \pm 0.3$ \\
Total hole visits & $14.8 \pm 2.1$ & $24.8 \pm 1.8^{*}$ & $17.0 \pm 2.4$ \\
Search strategy & & & \\
Latency (s) from center & $8.4 \pm 1.4$ & $14.0 \pm 1.4^{\#}$ & $11.8 \pm 2.1$ \\
Latency (s) first hole visit & $13.9 \pm 0.8$ & $16.0 \pm 2.6$ & $18.4 \pm 0.7^{\#}$ \\
\% Serial & $16.5 \pm 5.2$ & $28.2 \pm 3.6$ & $36.6 \pm 10.2^{\#}$ \\
\% Perseveration & $48.6 \pm 5.8$ & $39.3 \pm 5.2$ & $52.1 \pm 5.1$ \\
Anxiety related & & & \\
Latency (s) to rim & $63.0 \pm 13.1$ & $55.1 \pm 12.4$ & $69.9 \pm 8.5$ \\
Number of rim dips & $12.8 \pm 1.4$ & $18.4 \pm 2.0^{*}$ & $11.1 \pm 1.2$ \\
Number of boli & $1.1 \pm 0.7$ & $0.8 \pm 0.4$ & $1.3 \pm 0.8$ \\
\hline
\end{tabular}

Data are presented as mean \pm S.E.M.; $p<.05 *$ versus other groups; \# versus VEH

Bold italic indicates significant differences

$31.3 \pm 4.3 ; 7 x$ MIF $39.3 \pm 2.9$. Thymus weight was lower in both MIF groups, but passed statistical significance ( $F$ (3, $34)=3.100 ; p=.059)$ : thymus in $\mathrm{mg}$, mean \pm SEM: VEH $411.0 \pm 38.9 ; 1 x M I F 371.5 \pm 15.1 ; 7 x M I F \quad 321.1 \pm 23.6$.

\section{Experiment 3: Metabolism and Membrane Transport of Mifepristone}

\section{In Vivo Steroid Uptake in Brain}

In experiment 1 , the steroid profiles of rat brain and plasma made with LC/MS/MS showed that after oral treatment with $50 \mathrm{mg} / \mathrm{kg} / \mathrm{day}$, MIF could not be detected in plasma at either 1.5 or $3 \mathrm{~h}$ after the fifth and last treatment. Neither could any of its metabolites. In contrast, MIF was detectable in the brain with no significant difference between both time points, although individual variability in brain MIF levels was quite high. Comparable but more consistent levels were found for RU42633 in brain after treatment with MIF (Fig. 5). The mono-demethylated metabolite was also present at very low, but detectable levels in plasma. Moreover, plasma levels significantly correlated with brain levels for MIF-treated animals $\left(r^{2}=0.52, p<.01\right)$. Corticosterone levels in brain also correlated strongly with plasma levels $\left(r^{2}=0.48, p<.01\right)$ as determined with LC/MS/MS, and the latter values were validated with ${ }^{125} \mathrm{I}$-corticosterone radioimmunoassay $\left(r^{2}=0.89, p<.01\right.$; data not shown). After oral treatment with MIF, corticosterone levels increased significantly in plasma $(F(2,15)=7.94, p<.01)$ (Fig. 5). In brain, the increase did not reach statistical significance. MIF treatment did not affect adrenal or thymus weight nor body weight.
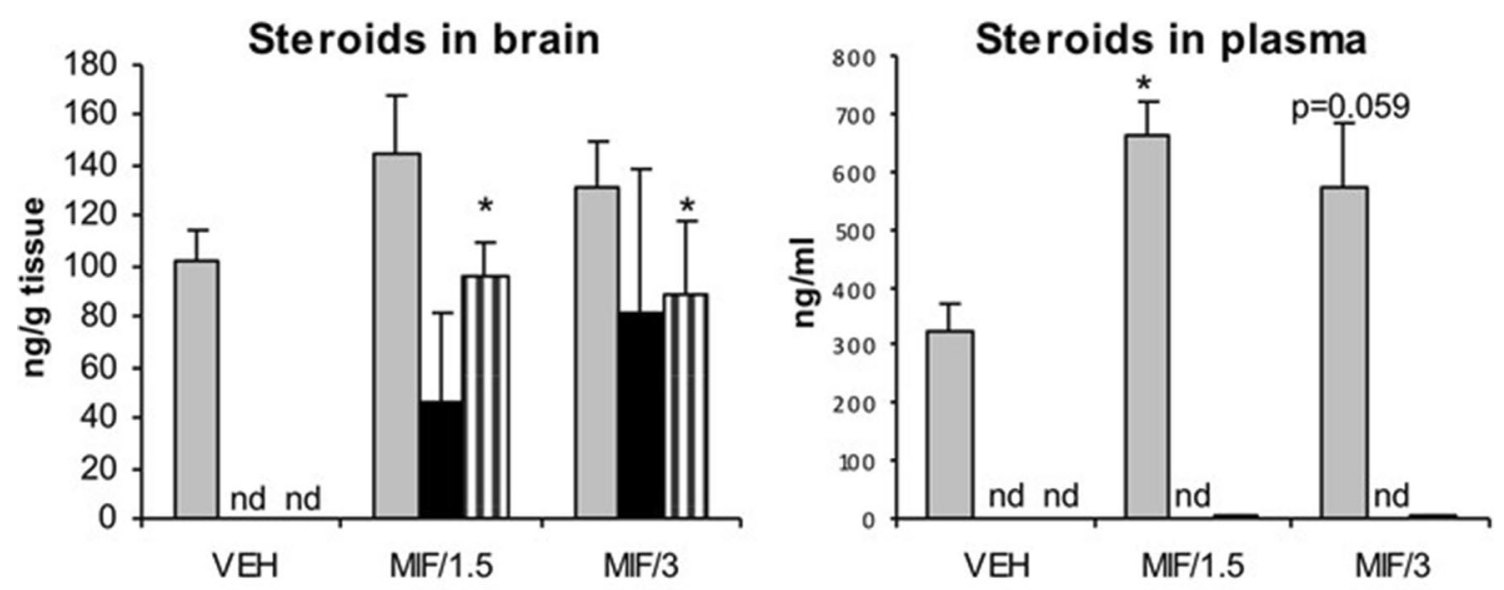

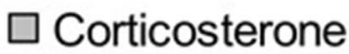

Fig. 5 Steroid levels at 1.5 or $3 \mathrm{~h}$ after the last oral administration of $50 \mathrm{mg} / \mathrm{kg}$ mifepristone; levels of mifepristone were undetectable in plasma, but clearly detectable in brain although with high variability. Brain RU42633 levels were significantly higher in MIF-treated animals compared to vehicle treated rats $\left(F_{(2,15)}=13.12, p<.01\right)$. Corticosterone levels were significantly higher in plasma but not in brain of rats treated with $\operatorname{MIF}\left(F_{(2,15)}=7.94, p<.01\right)$ compared to vehicle -treated rats. The concentrations of RU42848 and RU42698 were below the detection limit in both plasma and brain. $N=4-6$, shown is mean $+\operatorname{SEM}, * p<.05$, Tukey post hoc test. Note the difference in scale 


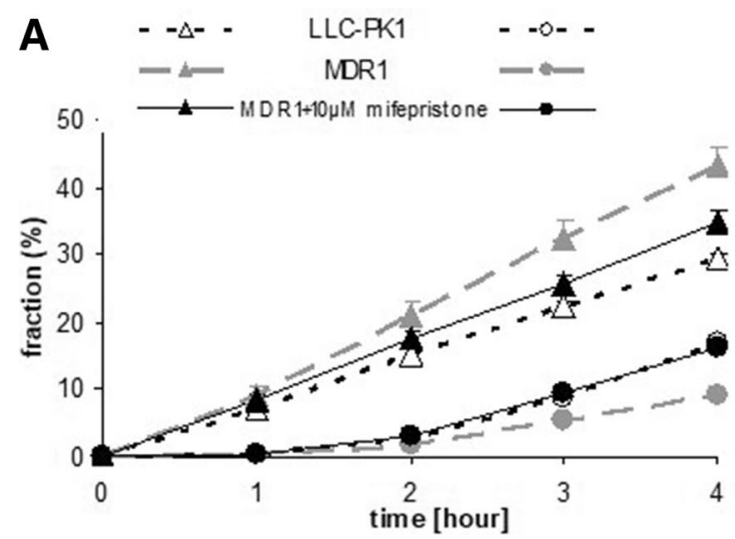

Fig. 6 a Fraction of activity of ${ }^{3} \mathrm{H}$-cortisol present in medium at different time points after adding $15 \mathrm{nM}{ }^{3} \mathrm{H}$-cortisol to the opposite compartment at $t=0$ in absence or presence of MIF. Transepithelial transport from basal to apical compartment and vice versa was measured in MDR1-transfected LLC-PK1 monolayers. Repeated measures ANOVA showed a significant time * cell type * MIF * direction of transport interaction $(p<.01)$. In the presence of $10 \mu \mathrm{M}$ MIF, trans-

\section{Inhibition of Cortisol Transport In Vitro}

The in vitro experiments confirmed our previous observations (Karssen et al. 2001) that in MDR1-monolayers, cortisol was transported in a highly polarized fashion (Fig. 6a). In presence of $10 \mu \mathrm{M} \mathrm{MIF}$, this transport was inhibited. ANOVA followed by post hoc analysis shows that at $t=4$ in presence of MIF, MDR1-transfected monolayers were not different from untransfected monolayers with regard to transport of ${ }^{3} \mathrm{H}$-cortisol, while both were statistically different from the untreated MDR1 monolayers. $100 \mu \mathrm{M}$ MIF was not able to further enhance the inhibitory action on cortisol transport (data not shown).

As the three main metabolites of MIF are structurally closely related to MIF, they may inhibit Pgp as well. Therefore, we tested the ability to inhibit cortisol transport of a mix of MIF and metabolites at therapeutically relevant concentrations (Lähteenmäki et al. 1987). A mix of MIF, RU42848, RU42698 (2.5 $\mu \mathrm{M}$ each), and $6 \mu \mathrm{M}$ RU42633 affected cortisol transport in MDR1 monolayers to a similar extent as $10 \mu \mathrm{M}$ MIF alone (Fig. 6b), whereas $2.5 \mu \mathrm{M}$ MIF alone inhibited transport to a minor extent only (data not shown).

\section{In Vivo Uptake of ${ }^{3} \mathrm{H}$-Cortisol: Effect of Mifepristone Pretreatment}

In a preliminary experiment, at $45 \mathrm{~min}$ after ${ }^{3} \mathrm{H}$-cortisol, blood plasma radioactivity was Veh $(n=7)$ versus MIF $(n=8), 0.88$ versus $0.65 \mathrm{nCi} / \mathrm{ml}$, while in brain, Veh versus

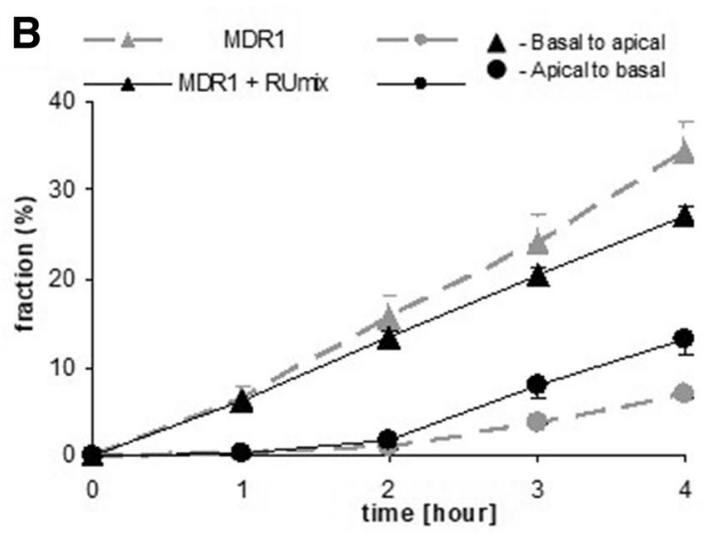

port of ${ }^{3} \mathrm{H}$-cortisol in monolayers of MDR1-transfected cells is inhibited and not different from transport of cortisol in monolayers of hosts cells. Data are presented as mean \pm SEM of three wells. MIF did not affect cortisol transport in untransfected monolayers (data not shown). b A mix of MIF and its three main metabolites at therapeutically relevant concentrations(see text) inhibits the transport of ${ }^{3} \mathrm{H}$-cortisol in MDR1-transfected monolayers

MIF was 0.08 versus $0.11 \mathrm{nCi} / \mathrm{mg}$ tissue. Although the amount of radioactivity in MIF-treated animals was not significantly enhanced in any tissue or plasma, the blood/ brain ratio of radioactivity administered as ${ }^{3} \mathrm{H}$-cortisol was significantly increased in MIF-treated animals, indicating a facilitation of cortisol uptake into the brain. The fold increase $(1.9 \mathrm{x})$ is less than in Pgp knock-out mice as previously determined (3.5x) (Karssen et al. 2001).

\section{Discussion}

The current data extend in male mice and rats the notion that a single challenge with MIF interferes with glucocorticoid feedback causing a long-lasting elevation of corticosterone secretion (Ratka et al. 1989; Dalm et al. 2008). Moreover, we found that at $24 \mathrm{~h}$ after ingestion of MIF, stress responsivity is profoundly enhanced. However, upon repeated high-dose MIF $(200 \mathrm{mg} / \mathrm{kg}$ ) daily administration, the circadian- and stress-induced HPA-axis activity are abolished. This apparent GR agonism of MIF upon repeated administration was previously also reported (Havel et al. 1996; Wulsin et al. 2010; van der Veen et al. 2013; Solomon et al. 2014; van den Heuvel et al. 2016; Nguyen et al. 2017, 2018; Kroon et al. 2018); however, with the lower doses in these studies, stress responsivity was attenuated rather than abolished (see also Fig. 5). At the same time, the weight of the adrenals was increased in our study. Adrenal weight was not altered with the lower 20-fold lower dose of MIF over 5 days (Wulsin et al. 2010) or fourfold lower dose (exp 3), and decreased if a 3-10-fold lower dose of MIF was administered over a 
longer time period of two weeks (Havel et al. 1996; Kroon et al. 2018). Thymus weights were consistently decreased, although not significant in the current study. As mentioned, this daily administration showing agonism contrasts with the continuous i.c.v. and twice a day high dose of MIF in that the latter two conditions produce in rodents disinhibition of the HPA axis in the circadian rise and following stress (van Haarst et al. 1996; Revsin et al. 2009).

These findings raise the question how the disinhibitory effect of acute MIF can abruptly change into an enduring inhibitory one upon repeated daily administration, particularly at doses in the range of therapeutic efficacy. A second, equally important question is, whether the current data contribute to understanding the apparent reset of the stress system achieved with MIF (Ratka et al. 1988; Hu et al. 2012). Various factors may contribute to this switch of GR antagonism to an apparent agonism, and ability to reset. These include (i) MIF kinetics: metabolism and penetration to GR feedback sites in brain and pituitary, (ii) dynamics of HPAaxis feedback regulation, (iii) differential signaling routes of MIF- and cortisol-occupied GR beyond HPA-axis regulation, and (iv) the brain MRs.

\section{MIF Kinetics}

MIF is rapidly cleared because in rodents the antagonist is not bound to plasma proteins and rapidly metabolized, while in human blood MIF is extensively protected to degradation because of binding with high affinity to $a_{1}$ glycoprotein (Heikinheimo et al. 1987). We found that after a $50 \mathrm{mg} / \mathrm{kg}$ rat dose orally given during 5 days, after the fifth and last administration MIF is already depleted from the circulation in a 90-min post-ingestion interval, while low amounts of the antagonist and its metabolite RU42633 are retained in the brain for at least $3 \mathrm{~h}$ and in the same concentration range as corticosterone.

The in vitro experiments using monolayers of pig kidney epithelial cells (LLC-PK1) stably expressing human MDR1 Pgp (Karssen et al. 2001) showed that MIF was capable of facilitating the transport of cortisol. We have previously shown that the uptake of dexamethasone and cortisol is hampered by Pgp at the blood-brain barrier in rodents and humans (Meijer et al. 1998; Karssen et al. 2001; Mason et al. 2012). MIF blocks Pgp, so cortisol cannot be bound and thus is not exported by the mdr transporter, hence a higher uptake and retention of cortisol. In an in vivo experiment, it was indeed demonstrated that a higher uptake of radioactivity in brain relative to blood occurred if ${ }^{3} \mathrm{H}$-cortisol is infused in animals pretreated with a high dose of MIF. The finding shows that repeated MIF could increase accumulation of the endogenous glucocorticoids in the brain of adrenally intact animals by blocking Pgp at the blood-brain barrier (Fig. 7).

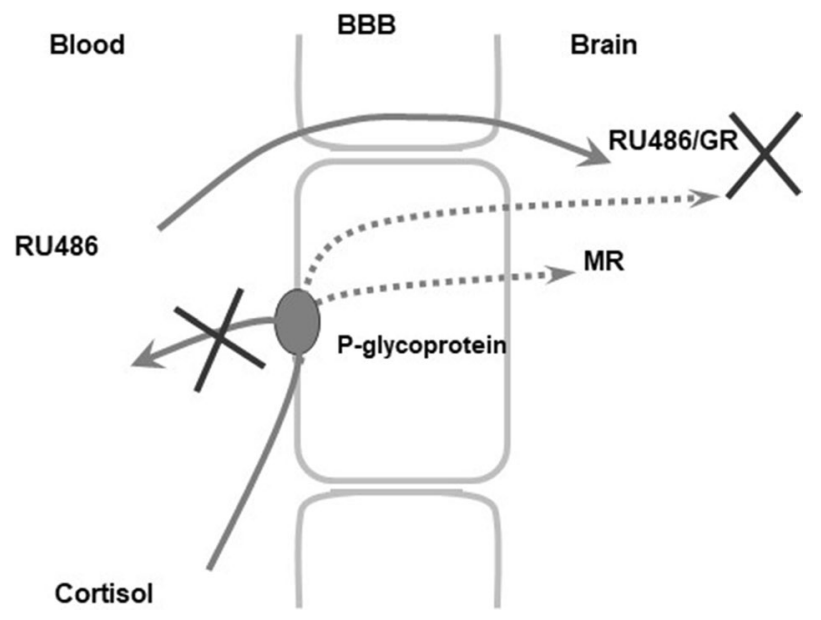

Fig. 7 Hypothesized MIF-induced facilitation of cortisol brain uptake through inhibition of the efflux transporter P-glycoprotein at the blood-brain barrier. Under normal conditions, cortisol is hampered to enter the brain due to active outwards directed transport at the bloodbrain barrier mediated by P-glycoprotein (Karssen et al. 2001). In the presence of MIF, this efflux is blocked facilitating the uptake of cortisol into the brain. The ensuing increased cortisol concentration will not lead to increased activation of GR, since this receptor is blocked by the high concentrations of MIF. However, increased activation of the MR is predicted to affect cognitive performance and neuroendocrine regulation. $\mathrm{X}$ indicates blockade of Pgp by MIF, which facilitates cortisol penetration through the blood-brain barrier and blockade of cortisol binding to GR. Dotted line is preferred cortisol route after Pgp blockade by MIF

In AtT 20 cells, MIF translocated the GR to the cell nucleus and induced DNA binding and MIF potentiated the cell nuclear translocation and DNA binding of corticosterone (Spiga et al. 2011). in vivo, MIF (20 mg/kg)-administered s.c. to ADX rats induced translocation and DNA binding of GR to nuclei of hippocampus 60 min following administration (van Eekelen et al. 1987; Spiga et al. 2011). The retention of the MIF-GR complex in pituitary nuclei was even more than twofold higher than in hippocampus. Pretreatment of the ADX rats with MIF did not inhibit but rather potentiated the nuclear retention of corticosterone $(3 \mathrm{mg} / \mathrm{kg}$ ) in hippocampal and pituitary nuclei; however, the effect was near trend level $(p<0,06)$ (Spiga et al. 2011). Whether this also occurs in vivo in intact animals with circulating corticosterone is not known.

In conclusion, the data show that in rodents MIF is rapidly cleared from the circulation but retained and bound to GR in hippocampal and pituitary cell nuclei and DNA. Most interestingly, MIF is a substrate for mdr transporters in the blood-brain barrier, and therefore in rodents the uptake and retention of exogenous cortisol is facilitated (Gruol et al. 1994; Lecureur et al. 1994; Gaillard et al. 1984; Karssen et al. 2001, 2005, 2004, 2002). Collectively, these data support the idea that at least in rodents very high doses of MIF 
are needed at the pituitary and brain level to overcome its rapid metabolism and the facilitated uptake and retention of cortisol.

\section{HPA-Axis Dynamics}

One possibility to explain the sudden refractoriness to repeated MIF administration is that the pituitary ACTH stores are depleted. Such depletion is a common observation following ADX when after the initial surge in readily releasable ACTH minimum pituitary levels of irACTH are attained after 1-3 days. Meanwhile, synthesis of POMC is stepped up and a condition of several folds higher ACTH level is reached 1 week after ADX, which still can be further elevated by stress exposure (van Dijk et al. 1981; Jacobson et al. 1989). However, ACTH levels were increased during twice a day of MIF for 4 days (Revsin et al. 2009). It is therefore unlikely that ACTH exhaustion has occurred, but for a conclusive answer, however, the effect of MIF on pituitary and plasma ACTH needs to be studied still on a day-by-day basis.

An alternative explanation can be a recurrent negative feedback. After a single MIF challenge, corticosterone remained elevated for $16 \mathrm{~h}$, while the genomic effects will persist even longer. Indeed, at $24 \mathrm{~h}$, the 1xMIF-treated animals were capable of mounting a profound corticosterone response. Our study suggests a recurrent pattern of GRmediated actions including negative feedback, which are transiently interrupted by daily application of the GR antagonist. We propose therefore that the HPA axis progressively adapts to this daily cycle of GR blockade and subsequent GR activation. Hence, during the seventh day of GR antagonist administration, the circadian corticosterone pattern may have become similar to that observed in control mice. Naturally, this assumption needs proof by measuring the effect of MIF on basal and stress induced on a day-by-day basis, and to compare this study with twice a day or continuous MIF administration thought to maintain disinhibition.

\section{MIF and Cortisol Signaling Via GR}

The apparent agonism of MIF that is observed in some contexts may differ from the endogenous agonism via cortisol in several ways. First, it has been proposed that MIF-GR is much more potent in exerting transcriptional transrepression than transactivation activity (Heck et al. 1994). This effectively could mean that-once endogenous corticosterone levels are low-part of the GR-dependent negative feedback does get activated by MIF via transrepression (De Bosscher et al. 2003, 2016). This is consistent with the HPA-axis phenotype of the GR ${ }^{\mathrm{dim} / \mathrm{dim}}$ mouse, where transcription of the $P o m c$ gene and memory performance are disrupted, because of its inability for GR homodimerization and transactivation, while the transrepression-dependent glucocorticoid negative feedback on ACTH release is mostly intact (Reichardt et al. 1998; Oitzl et al. 2001). Also, partial agonism of MIF via classical transactivation cannot be excluded in some cell types, and over time. For instance, in simple reporter gene assays, the extent of partial agonism could be doubled by overexpression of the SRC-1A coactivator (Meijer et al. 2005) that is relatively abundant in the core of the HPA axis (Meijer et al. 2000). Prolonged exposure to either continuous MIF, or alternating MIF and corticosterone in the mice studies, therefore has an unpredictable outcome, that may moreover develop over time, given that the expression of coactivators themselves may be regulated over time (Meijer et al. 2005).

\section{Mineralocorticoid Receptors}

Irrespective of phasic or continuous GR blockade, corticosterone binding to the MR is not hampered by MIF (Reul et al. 1990). MR is known to mediate control over appraisal processes, behavioral reactivity to novel experiences, and the onset of HPA-axis activity (Joëls et al. 2008; de Kloet and Joëls 2017; Joëls and de Kloet 2017). The changes in corticosterone action via MR activation were reflected by the lower expression of hippocampal MR mRNA for the 1xMIFgroup in all subregions, whereas expression was increased in the CA2 region of the hippocampus for 7xMIF-group. Interestingly, GR blockade after MIF treatment per os for three weeks, increased total hippocampal MR mRNA expression by 1.5 compared to controls (Bachmann et al. 2003). Therefore, it would be of interest to determine longitudinal effects of repeated GR blockade on MR function, particularly since previous studies have clearly shown that MR and GR interact in control of HPA-axis activity (Spencer et al. 1998).

Four days of MIF with the last administration given 90 min prior to the initial test promoted an active coping style (Wulsin et al. 2010). Acute MIF interfered with retention of this acquired immobility response, suggesting memory impairment (de Kloet et al. 1988). Chronic MIF, leaving MR active, improved memory performance (Oitzl et al. 1998). In line with this phenotype of a relative brain MR excess, studies with mouse mutants overexpressing MR in limbic forebrain revealed enhancement of memory (Ferguson and Sapolsky 2007; Lai et al. 2007; Kolber et al. 2008), perseveration of learned behavior (Harris et al. 2013), and reduction of anxiety (Rozeboom et al. 2007).

Previously, the pharmacological blockade of MR had also shown altered appraisal processes and selection of the appropriate behavioral response, i.e., search strategy (Oitzl and de Kloet 1992; Oitzl et al. 1994, 1997; Schwabe et al. 2010, 2013). In the current study, twenty-four-hours following repeated GR antagonism, mice used the serial search 
strategy more often, compared to controls. This strategy increases the likelihood that the animals will visit all possible escape routes that the circular hole board provides (during the exploration trial, all holes were closed). Indeed, the choice of applied strategy does affect performance in spatial learning trials (Dalm et al. 2000). In the current study, following 1xMIF, mice were initially slower to move away from the start center, but subsequently hyperactive on the circular hole board. This could indicate a change in the level of anxiety induced by previous GR antagonism. If so, then the effect is transient as repeated GR antagonism did not induce any of the above described features.

The elegant study by (Wulsin et al. 2010) revealed that one week treatment with a twentyfold lower dose of MIF i.p. $(10 \mathrm{mg} / \mathrm{kg}$ rat $)$ produced an attenuated HPA-axis response to a forced swim stressor. Interestingly, this course of MIF treatment also evoked a differential pattern of activation and inhibition of central inputs to the PVN. The ventral subiculum of the hippocampus and all regions of the medial frontal cortex showed enhanced stress-induced c-Fos activity after daily GR blockade, while the c-Fos response was reduced in other subregions of the hippocampus and in the amygdala. These data suggest that MIF enhanced inhibitory and suppressed excitatory inputs to the PVN that collectively may contribute to the downregulation of HPA-axis activity. To exert these effects, MIF likely may have recruited distinct cocktails of co-regulators of the GR in the corticosteroid target neurons of the limbic brain (Meijer et al. 2000; Meijer et al. 2005; Lachize et al. 2009; Ronacher et al. 2009; Zalachoras et al. 2013). In conclusion, as a result of GR blockade, the MR becomes relatively more activated. This combination of increased MR activity and blockage of GR may result in an altered function of limbic-frontocortical afferents and reset of neuroendocrine control of the HPA axis.

\section{Implications for Clinical Studies}

One obvious question is how the current findings in the rodent may contribute to the clinical observations showing high-dose MIF efficacy. Recent studies referred to the need of circulating MIF levels exceeding $1637 \mathrm{ng} / \mathrm{ml}$ blood with a dosage of $1200 \mathrm{mg} /$ day for 7 days in order to achieve the strongest association with treatment response in psychotic depression. This association in treatment response was followed by a weaker, but still significant association with increased basal ACTH and cortisol levels (Block et al. 2018), which lasted several weeks beyond the termination of MIF treatment. Before the conclusions on reset of the stress system from animal experiments can be extended, more data on stress responsivity in clinical studies are required, however.
The current data raise the possibility that MIF's primary target is extrahypothalamic. A recent study demonstrated in rats that chronic MIF released from a $150 \mathrm{mg}$ s.c. implanted pellet reduces (compulsatory) alcohol intake in dependent rats (Vendruscolo et al. 2012). These effects were reproduced by i.p. administration of 30-60 mg MIF at $90 \mathrm{~min}$ prior to alcohol intake as well as after $10-30 \mu \mathrm{g}$ local administration bilaterally in the central amygdala. The data were reproduced in humans with MIF and the selective GR antagonist C-113176 (Vendruscolo et al. 2015). It was also found in rats that alcohol withdrawal and protracted abstinence produced changes in GR mRNA and bio-active phosphorylated GR rather than MR mRNA expression in the limbic-prefrontocortical and mesolimbic dopaminergic system. Using a systems biology approach, GR was identified as a master controller of downstream gene regulatory networks in these extrahypothalamic regions (Repunte-Canonigo et al. 2015).

When it concerns diseases precipitated by psychological stress, the ability of MIF and related compounds to readily re-establish the setpoint of the stress system is of prime importance. Such a reset would require restoration of an imbalance in MR/GR-mediated processes in the brain. A striking example is found in rats showing a deterioration of cellular and behavioral phenotype during chronic unpredictable stress, which is entirely restored with a single course of MIF (Hu et al. 2012). Transcriptome analysis (Datson et al. 2012) revealed that in laser-dissected hippocampal dentate gyrus of these chronically stressed animals, MIF treatment affected 107 genes, which were mostly different from the ones observed in the stressed group. We found that CREBbinding protein (CREB-BP) was normalized by MIF treatment to levels observed in control animals. Next to the GR, CREB-signaling, therefore, may play a central role in mediating the chronic stress effects on neurogenesis, LTP, and calcium currents in the dentate gyrus (Karst and Joëls 2003; van Gemert and Joëls 2006; Datson et al. 2012, 2013) and perhaps in other (meso)limbic-frontocortical regions as well.

In humans, bio-availability of MIF is extended because the steroid circulates bound to $a_{1}$ glycoprotein and therefore has a much longer half-life than in rodents, where this binding protein is absent (Heikinheimo et al. 1987). Moreover, in recent studies it was noted that although there is an obvious association with MIF's action on the HPA axis, it cannot be excluded that the compound's pharmacology is due to blockade of GRs in limbic-frontocortical and mesocortical dopaminergic circuits involved in mood, anxiety, reward, and motivation. This is reinforced by the MIF-induced change in stress circuit activation favoring inhibitory inputs to the PVN (Wulsin et al. 2010), the systems biology approach pointing to the GR in these regions as master controller (RepunteCanonigo et al. 2015) and the MR:GR balance hypothesis (de Kloet et al. 2018). Although the required circulating 
MIF levels beyond $1637 \mathrm{ng}$ MIF/ml blood certainly are an important first step, more data on HPA-axis regulation and extrahypothalamic effects as well as the role of (epi)genetic factors are needed to predict treatment response in psychotic depression.

\section{Perspectives}

MIF (or Korlym ${ }^{\circledR}$ ) is indicated for treatment of hyperglycemia during Cushing's Syndrome and was found to cause a clinically significant metabolic improvement with less depressive symptoms, improved cognitive performance, and an increased quality of life (Fleseriu et al. 2012). This indication is based on the correction of glucocorticoid-induced glucose intolerance and diabetes mellitus (Beaudry et al. 2014; Teich et al. 2016; van den Heuvel et al. 2016; Moraitis et al. 2017; Kroon et al. 2018; Meijer et al. 2018).

Glucocorticoid action is of course needed for allocation of energy substrates to tissues in need during coordination of circadian events, immune and inflammatory defense reactions, stress coping, and adaptation (Picard et al. 2014; Hollis et al. 2015). If defense reactions essential for health exceed control by endogenous corticosterone and cortisol, they may become damaging themselves (Munck et al. 1984; Sapolsky et al. 2000). The exogenous (synthetic) glucocorticoids are very effective anti-inflammatory and immune suppressive agents. However, the adverse effects on energy metabolism, pituitary ACTH release, and brain function may become a serious concern. Important progress has been made by exploiting SGRM's for identification of tissue and context-specific modulation of GR-mediated processes. This is important because the 'golden bullet' (Meijer et al. 2018) would be a compound that solely treats inflammatory and immune processes without side effects, or that solely restores deregulated metabolism, or that targets only central circuits underlying depression.

Potential new applications of the SGRM's are being tested. For instance, C-108297 (3,5 mg/mouse) for 4 days given to Wobbler mice, an animal model of human amyotrophic lateral sclerosis (ALS), normalizes indices for neurogenesis and facilitates recovery from a pro-inflammatory phenotype in hippocampus (Meyer et al. 2014). The selective GR antagonist C-113176 displayed a similar protective pharmacology in the Wobbler mice, and additionally prevented spinal cord pathology, while displaying anti-inflammatory and anti-glutamatergic activity (Meyer et al. 2018).

MIF (30 mg/kg rat ip), and the much more effective C-108297 (20 mg/kg) and C-113176 (10 mg/kg) at a dose of 20 and $10 \mathrm{mg} / \mathrm{kg}$, respectively, twice a day for 5 days, all reversed the precipitation of Alzheimer pathology and cognitive impairment in an animal model generated by hippocampal amyloid- $\beta_{25-35}$ administration, while normalizing plasma corticosterone levels (Pineau et al. 2016). Another interesting new ligand is $\mathrm{C}-118335$, a mixed GR modulator/MR antagonist ( $100 \mathrm{mg} / \mathrm{kg}$ male rat), which displayed clearly GR agonistic activity in gene regulation and HPAaxis suppression after a single s.c. injection, but blocked memory storage (Atucha et al. 2015), while being inactive on coping style (Nguyen et al. 2017, 2018). Hence, more selective GR modulators will be important for targeted treatment.

\section{Concluding remarks}

The reset of stress system activity by MIF could be due to the following factors: (1) The detrimental effects of high corticosteroid concentrations via GR activation are prevented by GR antagonism. This approach has obvious benefit during continuous or high-frequency blockade of the GR. (2) The high circulating corticosterone concentrations may have caused a long-lasting rebound suppression of HPAaxis activity, particularly since MIF is rapidly cleared. (3) MIF may become an agonist in transrepression (Heck et al. 1994) and promote cell- and context-dependent recruitment of coactivators and co-repressors in a cell-specific fashion in brain stress circuitry (Meijer et al. 2018; Zalachoras et al. 2013, 2016). (4) Enhanced brain MR activation may become prominent relative to the MIF-modulated GR. The altered MR:GR balance could be part of a compensatory mechanism producing altered patterns of inhibitory and excitatory circuits underlying reset of stress system activity (De Kloet et al. 1998; de Kloet et al. 2005, 2018; Sousa 2016; Wulsin et al. 2010). This includes the role of MR and GR as homoor heterodimers in binding to GRE's, transcription factors, and co-regulators (Mifsud and Reul 2016; Van Weert et al. 2017; Matosin et al. 2018; Meijer et al. 2018) as well as their rapid non-genomic actions (Di et al. 2003; Karst et al. 2005, 2010; Groeneweg et al. 2012; Hill and Tasker 2012).

Chronic stress models of depression display glucocorticoid resistance caused by imbalance in the afferent limbicprefrontocortical pathways innervating the hypothalamic PVN and mesolimbic dopaminergic system (Ulrich-Lai and Herman 2009). The striking finding with MIF and related compounds is that the high doses required to affect pituitary and brain regulation of the HPA axis seem capable of readily resetting stress system activity. It is a great challenge to discover if reset of stress system activity is the cause or the consequence of MIF's efficacy in the treatment of stressrelated neuropsychiatric disorders.

Acknowledgements The inspiring leadership of Melly S. Oitzl in the research on stress, brain, and behavior is gratefully acknowledged. Technical assistance of Ewald Engst and Julia Straker is gratefully acknowledged. 
Author Contributions SD and AMK performed the experiments as part of their $\mathrm{PhD}$ research, wrote the methods and results section, and made the figures. OCM evaluated the manuscript for mechanistic underpinning of the GR antagonist action and wrote part of the discussion. JKB incorporated text on specific knowledge of mifepristone and novel GR modulators in the text. ERdK designed the study, wrote the overview on GR antagonists in the introduction, and integrated the results in the abstract and discussion sections. All authors critically reviewed the manuscript and gave approval to the final version of the manuscript.

Funding Funding was provided by NWO \#015.01.076 (SD) and the Royal Netherlands Academy of Arts and Sciences (ERdK). Corcept Therapeutics has provided Mifepristone for the studies.

\section{Compliance with Ethical Standards}

Conflict of interest SD and AMK report no conflict of interest. ERdK is on the Scientific Advisory Board of the DynaCorts Group and owns stock of Corcept Therapeutics. OCM receives funding from Corcept Therapeutics. JKB is an employee of Corcept Therapeutics, which develops novel GR ligands.

Open Access This article is distributed under the terms of the Creative Commons Attribution 4.0 International License (http://creativeco mmons.org/licenses/by/4.0/), which permits unrestricted use, distribution, and reproduction in any medium, provided you give appropriate credit to the original author(s) and the source, provide a link to the Creative Commons license, and indicate if changes were made.

\section{References}

Arp JM, ter Horst JP, Loi M et al (2016) Blocking glucocorticoid receptors at adolescent age prevents enhanced freezing between repeated cue-exposures after conditioned fear in adult mice raised under chronic early life stress. Neurobiol Learn Mem 133:30-38. https://doi.org/10.1016/j.nlm.2016.05.009

Atucha E, Zalachoras I, van den Heuvel JK et al (2015) A mixed glucocorticoid/mineralocorticoid selective modulator with dominant antagonism in the male rat brain. Endocrinology 156:4105-4114. https://doi.org/10.1210/en.2015-1390

Bachmann CG, Linthorst ACE, Holsboer F, Reul JMHM (2003) Effect of chronic administration of selective glucocorticoid receptor antagonists on the rat hypothalamic-pituitary-adrenocortical axis. Neuropsychopharmacology 28:1056-1067. https://doi. org/10.1038/sj.npp.1300158

Beaudry JL, Dunford EC, Teich T et al (2014) Effects of selective and non-selective glucocorticoid receptor II antagonists on rapidonset diabetes in young rats. PLoS ONE 9:e91248. https://doi. org/10.1371/journal.pone.0091248

Belanoff JK, Flores BH, Kalezhan M et al (2001) Rapid reversal of psychotic depression using mifepristone. J Clin Psychopharmacol 21:516-521. https://doi.org/10.1097/00004714-20011 0000-00009

Belanoff JK, Rothschild AJ, Cassidy F et al (2002) An open label trial of C-1073 (mifepristone) for psychotic major depression*. Biol Psychiatr 52:386-392. https://doi.org/10.1016/S0006 -3223(02)01432-4

Blasey CM, Debattista C, Roe R et al (2009) A multisite trial of mifepristone for the treatment of psychotic depression: a site-bytreatment interaction. Contemp Clin Trials 30:284-288. https:// doi.org/10.1016/j.cct.2009.03.001
Blasey CM, Block TS, Belanoff JK, Roe RL (2011) Efficacy and safety of mifepristone for the treatment of psychotic depression. J Clin Psychopharmacol 31:436-440. https://doi.org/10.1097/ JCP.0b013e3182239191

Block T, Petrides G, Kushner H et al (2017) Mifepristone plasma level and glucocorticoid receptor antagonism associated with response in patients with psychotic depression. J Clin Psychopharmacol 37:505-511. https://doi.org/10.1097/JCP.0000000000000744

Block TS, Kushner H, Kalin N et al (2018) Combined analysis of mifepristone for psychotic depression: plasma levels associated with clinical response. Biol Psychiatr 84:46-54. https://doi. org/10.1016/j.biopsych.2018.01.008

Dalm S, Grootendorst J, R de KE SOM (2000) Quantification of swim patterns in the Morris water maze. Behav Res Methods Instrum Comput. 32:134-139

Dalm S, Enthoven L, Meijer OC et al (2005) Age-related changes in hypothalamic-pituitary-adrenal axis activity of male C57BL/6J mice. Neuroendocrinology 81:372-380. https://doi. org/10.1159/000089555

Dalm S, Brinks V, van der Mark MH et al (2008) Non-invasive stress-free application of glucocorticoid ligands in mice. J Neurosci Methods 170:77-84. https://doi.org/10.1016/j.jneum eth.2007.12.021

Datson NA, Speksnijder N, Mayer JL et al (2012) The transcriptional response to chronic stress and glucocorticoid receptor blockade in the hippocampal dentate gyrus. Hippocampus 22:359-371. https://doi.org/10.1002/hipo.20905

Datson NA, van den Oever JME, Korobko OB et al (2013) Prior history of chronic stress changes the transcriptional response to glucocorticoid challenge in the dentate gyrus region of the male rat hippocampus. Endocrinology 154:3261--3272

de Kloet ER (1991) Brain corticosteroid receptor balance and homeostatic control. Front Neuroendocrinol 12:95-164. https://doi. org/10.1080/09614520701469617

de Kloet ER, Joëls M (2017) Brain mineralocorticoid receptor function in control of salt balance and stress-adaptation. Physiol Behav 178:13-20. https://doi.org/10.1016/j.physb eh.2016.12.045

de Kloet ER, De Kock S, Schild V, Veldhuis HD (1988) Antiglucocorticoid RU 38486 attenuates retention of a behaviour and disinhibits the hypothalamic-pituitary adrenal axis at different brain sites. Neuroendocrinology 47:109-115. https://doi.org/10.1159/00012 4900

De Kloet ER, Vreugdenhil E, Oitzl MS, Joëls M (1998) Brain corticosteroid receptor balance in health and disease. Endocr Rev 19:269-301

De Bosscher K, Vanden Berghe W, Haegeman G (2003) The interplay between the glucocorticoid receptor and nuclear factor-kappaB or activator protein-1: molecular mechanisms for gene repression. Endocr Rev 24:488-522

de Kloet ER, Joëls M, Holsboer F (2005) Stress and the brain: from adaptation to disease. Nat Rev Neurosci 6:463-475. https://doi. org/10.1038/nrn 1683

De Bosscher K, Beck IM, Ratman D et al (2016) Activation of the glucocorticoid receptor in acute inflammation: the SEDIGRAM concept. Trends Pharmacol Sci 37:4-16. https://doi.org/10.1016/j. tips.2015.09.002

de Kloet ER, Meijer OC, de Nicola AF et al (2018) Importance of the brain corticosteroid receptor balance in metaplasticity, cognitive performance and neuro-inflammation. Front Neuroendocrinol 49:124-145. https://doi.org/10.1016/j.yfrne.2018.02.003

DeBattista C, Belanoff J (2006) The use of mifepristone in the treatment of neuropsychiatric disorders. Trends Endocrinol Metab 17:117-121. https://doi.org/10.1016/j.tem.2006.02.006 
Deraedt R, Bonnat C, Busigny M et al (1985) Pharmacokinetics of RU 486. In: The antiprogestin steroid RU 486 and human fertility control. Springer, Boston, pp 103-122

Deuschle M, Weber B, Colla M et al (1998) Mineralocorticoid receptor also modulates basal activity of hypothalamus-pituitary-adrenocortical system in humans. Neuroendocrinology 68:355-360. https://doi.org/10.1159/000054384

Di S, Malcher-Lopes R, Halmos KC, Tasker JG (2003) Nongenomic glucocorticoid inhibition via endocannabinoid release in the hypothalamus: a fast feedback mechanism. J Neurosci 23:4850-4857

Dodt C, Kern W, Fehm L, Born J (1993) Antimineralocorticoid canrenoate enhances secretory activity of the hypothalamus-pituitary-adrenocortical (HPA) axis in humans. Neuroendocrinology 58:570-574. https://doi.org/10.1159/000126592

Ferguson D, Sapolsky R (2007) Mineralocorticoid receptor overexpression differentially modulates specific phases of spatial and nonspatial memory. J Neurosci 27:8046-8052. https://doi. org/10.1523/JNEUROSCI.1187-07.2007

Fleseriu M, Biller BMK, Findling JW et al (2012) Mifepristone, a glucocorticoid receptor antagonist, produces clinical and metabolic benefits in patients with Cushing's syndrome. J Clin Endocrinol Metab 97:2039-2049. https://doi.org/10.1210/jc.2011-3350

Flores BH, Kenna H, Keller J et al (2006) Clinical and biological effects of mifepristone treatment for psychotic depression. Neuropsychopharmacology 31:628-636. https://doi. org/10.1038/sj.npp.1300884

Gaillard RC, Riondel A, Muller AF et al (1984) RU 486: a steroid with antiglucocorticosteroid activity that only disinhibits the human pituitary-adrenal system at a specific time of day. Proc Natl Acad Sci 81:3879-3882. https://doi.org/10.1073/ pnas.81.12.3879

Garner B, Phillips LJ, Bendall S, Hetrick SE (2016) Antiglucocorticoid and related treatments for psychosis. Cochrane Database Syst Rev https://doi.org/10.1002/14651858.CD006995.pub2

Groeneweg FL, Karst H, de Kloet ER, Joëls M (2012) Mineralocorticoid and glucocorticoid receptors at the neuronal membrane, regulators of nongenomic corticosteroid signalling. Mol Cell Endocrinol 350:299-309. https://doi.org/10.1016/j.mce.2011.06.020

Gruol DJ, Zee MC, Trotter J, Bourgeois S (1994) Reversal of multidrug resistance by RU 486. Cancer Res 54:3088-3091

Harris AP, Holmes MC, de Kloet ER et al (2013) Mineralocorticoid and glucocorticoid receptor balance in control of HPA axis and behaviour. Psychoneuroendocrinology 38:648-658. https://doi. org/10.1016/j.psyneuen.2012.08.007

Havel PJ, Busch BL, Curry DL et al (1996) Predominately glucocorticoid agonist actions of RU-486 in young specific-pathogen-free Zucker rats. Am J Physiol 271:R710-R717

Heck S, Kullmann M, Gast A et al (1994) A distinct modulating domain in glucocorticoid receptor monomers in the repression of activity of the transcription factor AP-1. EMBO J 13:4087-4095. https://doi.org/10.1002/j.1460-2075.1994.tb06726.x

Heikinheimo O, Kontula K, Croxatto H et al (1987) Plasma concentrations and receptor binding of RU 486 and its metabolites in humans. J Steroid Biochem 26:279-284. https://doi. org/10.1016/0022-4731(87)90083-5

Hill MN, Tasker JG (2012) Endocannabinoid signaling, glucocorticoid-mediated negative feedback, and regulation of the hypothalamic-pituitary-adrenal axis. Neuroscience 204:5-16. https://doi. org/10.1016/j.neuroscience.2011.12.030

Hollis F, van der Kooij MA, Zanoletti O et al (2015) Mitochondrial function in the brain links anxiety with social subordination. Proc Natl Acad Sci 112:15486-15491. https://doi.org/10.1073/ pnas. 1512653112

Hu P, Oomen C, van Dam A-M et al (2012) a single-day treatment with mifepristone is sufficient to normalize chronic glucocorticoid induced suppression of hippocampal cell proliferation. PLoS ONE 7:e46224. https://doi.org/10.1371/journal.pone.0046224

Iglesias T, Verbeeck MAE, De Kloet RE et al (1991) Time- and region-dependent effect of adrenalectomy on neuropeptide gene expression in rat hippocampus and striatum. Mol Cell Neurosci 2:485-490. https://doi.org/10.1016/1044-7431(91)90015-G

Jacobson L, Akana SF, Cascio CS et al (1989) The adrenocortical system responds slowly to removal of corticosterone in the absence of concurrent stress*. Endocrinology 124:2144-2152. https:// doi.org/10.1210/endo-124-5-2144

Joëls M (2006) Corticosteroid effects in the brain: U-shape it. Trends Pharmacol Sci 27:244-250. https://doi.org/10.1016/j. tips.2006.03.007

Joëls M, de Kloet ER (1992) Control of neuronal excitability by corticosteroid hormones. Trends Neurosci 15:25-30. https://doi. org/10.1016/0166-2236(92)90345-9

Joëls M, de Kloet ER (2017) 30 Years of the mineralocorticoid receptor: the brain mineralocorticoid receptor: a saga in three episodes. J Endocrinol 234:T49-T66. https://doi.org/10.1530/JOE-16-0660

Joëls M, Karst H, DeRijk R, de Kloet ER (2008) The coming out of the brain mineralocorticoid receptor. Trends Neurosci 31:1-7. https ://doi.org/10.1016/j.tins.2007.10.005

Joëls M, Karst H, Sarabdjitsingh RA (2018) The stressed brain of humans and rodents. Acta Physiol (Oxf) 223:e13066. https:// doi.org/10.1111/apha.13066

Karssen AM, Meijer OC, van der Sandt IC et al (2001) Multidrug resistance P-glycoprotein hampers the access of cortisol but not of corticosterone to mouse and human brain. Endocrinology 142:2686-2694. https://doi.org/10.1210/endo.142.6.8213

Karssen AM, Meijer OC, van der Sandt ICJ et al (2002) The role of the efflux transporter P-glycoprotein in brain penetration of prednisolone. J Endocrinol 175:251-260. https://doi.org/10.1677/ joe. 0.1750251

Karssen AM, Meijer O, Pons D, de Kloet ER (2004) Localization of mRNA expression of p-glycoprotein at the blood-brain barrier and in the hippocampus. Ann N Y Acad Sci 1032:308-311. https ://doi.org/10.1196/annals.1314.048

Karssen AM, Meijer OC, Berry A et al (2005) Low doses of dexamethasone can produce a hypocorticosteroid state in the brain. Endocrinology 146:5587-5595. https://doi.org/10.1210/en.2005-0501

Karst H, Joëls M (2003) Effect of chronic stress on synaptic currents in rat hippocampal dentate gyrus neurons. J Neurophysiol 89:625633. https://doi.org/10.1152/jn.00691.2002

Karst H, Berger S, Turiault M et al (2005) Mineralocorticoid receptors are indispensable for nongenomic modulation of hippocampal glutamate transmission by corticosterone. Proc Natl Acad Sci 102:19204-19207. https://doi.org/10.1073/pnas.0507572102

Karst H, Berger S, Erdmann G et al (2010) Metaplasticity of amygdalar responses to the stress hormone corticosterone. Proc Natl Acad Sci U S A 107:14449-14454. https://doi.org/10.1073/pnas.09143 81107

Kolber BJ, Wieczorek L, Muglia LJ (2008) Hypothalamic-pituitaryadrenal axis dysregulation and behavioral analysis of mouse mutants with altered glucocorticoid or mineralocorticoid receptor function. Stress 11:321-338. https://doi.org/10.1080/10253 890701821081

Kroon J, Koorneef LL, van den Heuvel JK et al (2018) Selective glucocorticoid receptor antagonist CORT125281 activates brown adipose tissue and alters lipid distribution in male mice. Endocrinology 159:535-546. https://doi.org/10.1210/en.2017-00512

Lachize S, Apostolakis EM, van der Laan S et al (2009) Steroid receptor coactivator-1 is necessary for regulation of corticotropinreleasing hormone by chronic stress and glucocorticoids. Proc Natl Acad Sci USA 106:8038-8042. https://doi.org/10.1073/ pnas.0812062106 
Lähteenmäki P, Heikinheimo O, Croxatto H et al (1987) Pharmacokinetics and metabolism of RU 486. J Steroid Biochem 27:859-863

Lai M, Horsburgh K, Bae SE et al (2007) Forebrain mineralocorticoid receptor overexpression enhances memory, reduces anxiety and attenuates neuronal loss in cerebral ischaemia. Eur J Neurosci 25:1832-1842. https://doi.org/10.1111/j.1460-9568.2007.05427 . $\mathrm{x}$

Lecureur V, Fardel O, Guillouzo A (1994) The antiprogestatin drug RU 486 potentiates doxorubicin cytotoxicity in multidrug resistant cells through inhibition of P-glycoprotein function. FEBS Lett 355:187-191. https://doi.org/10.1016/0014-5793(94)01186-9

Loi M, Sarabdjitsingh RA, Tsouli A et al (2017) Transient prepubertal mifepristone treatment normalizes deficits in contextual memory and neuronal activity of adult male rats exposed to maternal deprivation. Eneuro. https://doi.org/10.1523/ENEUR O.0253-17.2017

Mason BL, Pariante CM, Thomas SA (2012) Changes in the brain accumulation of glucocorticoids in abcb1a-deficient CF-1 mice. J Neuroendocrinol 24:1440-1446. https://doi.org/10.111 $1 / \mathrm{j} .1365-2826.2012 .02353 . \mathrm{x}$

Matosin N, Halldorsdottir T, Binder EB (2018) Understanding the molecular mechanisms underpinning gene by environment interactions in psychiatric disorders: the FKBP5 model. Biol Psychiatr 83:821-830. https://doi.org/10.1016/j.biopsych.2018.01.021

Mayer JL, Klumpers L, Maslam S et al (2006) Brief treatment with the glucocorticoid receptor antagonist mifepristone normalises the corticosterone-induced reduction of adult hippocampal neurogenesis. J Neuroendocrinol 18:629-631. https://doi.org/ 10.1111/j.1365-2826.2006.01455.x

Meijer OC, De Lange ECM, Breimer DD et al (1998) Penetration of dexamethasone into brain glucocorticoid targets is enhanced in mdr1A P-glycoprotein knockout mice. Endocrinology 139:1789-1793

Meijer OC, Steenbergen PJ, De Kloet ER (2000) Differential expression and regional distribution of steroid receptor coactivators SRC-1 and SRC-2 in brain and pituitary. Endocrinology 141:2192-2199. https://doi.org/10.1210/endo.141.6.7489

Meijer OC, Kalkhoven E, van der Laan S et al (2005) Steroid receptor coactivator-1 splice variants differentially affect corticosteroid receptor signaling. Endocrinology 146:1438-1448. https ://doi.org/10.1210/en.2004-0411

Meijer OC, Koorneef LL, Kroon J (2018) Glucocorticoid receptor modulators. Ann Endocrinol (Paris) 79:107-111. https://doi. org/10.1016/j.ando.2018.03.004

Meyer M, Gonzalez Deniselle MC, Hunt H et al (2014) The selective glucocorticoid receptor modulator CORT108297 restores faulty hippocampal parameters in Wobbler and corticosteronetreated mice. J Steroid Biochem Mol Biol 143:40-48. https:// doi.org/10.1016/j.jsbmb.2014.02.007

Meyer M, Lara A, Hunt H et al (2018) The selective glucocorticoid receptor modulator cort 113176 reduces neurodegeneration and neuroinflammation in wobbler mice spinal cord. Neuroscience 384:384-396. https://doi.org/10.1016/j.neuroscien ce.2018.05.042

Mifsud KR, Reul JMHM (2016) Acute stress enhances heterodimerization and binding of corticosteroid receptors at glucocorticoid target genes in the hippocampus. Proc Natl Acad Sci U S A 113:11336-11341. https://doi.org/10.1073/pnas.1605246113

Moraitis AG, Block T, Nguyen D, Belanoff JK (2017) The role of glucocorticoid receptors in metabolic syndrome and psychiatric illness. J Steroid Biochem Mol Biol 165:114-120. https:// doi.org/10.1016/j.jsbmb.2016.03.023

Munck A, Guyre PM, Holbrook NJ (1984) Physiological functions of glucocorticoids in stress and their relation to pharmacological actions. Endocr Rev 5:25-44. https://doi.org/10.1210/ edrv-5-1-25
Murphy BE, Filipini D, Ghadirian AM (1993) Possible use of glucocorticoid receptor antagonists in the treatment of major depression: preliminary results using RU 486. J Psychiatry Neurosci 18:209-213

Nguyen ET, Streicher J, Berman S et al (2017) A mixed glucocorticoid/mineralocorticoid receptor modulator dampens endocrine and hippocampal stress responsivity in male rats. Physiol Behav 178:82-92. https://doi.org/10.1016/j.physb eh.2017.01.020

Nguyen ET, Caldwell JL, Streicher J et al (2018) Differential effects of imipramine and CORT118335 (glucocorticoid receptor modulator/mineralocorticoid receptor antagonist) on brain-endocrine stress responses and depression-like behavior in female rats. Behav Brain Res 336:99-110. https://doi.org/10.1016/j. bbr.2017.08.045

Oitzl MS, de Kloet ER (1992) Selective corticosteroid antagonists modulate specific aspects of spatial orientation learning. Behav Neurosci 106:62-71. https://doi.org/10.1037/0735-7044.106.1.62

Oitzl MS, Fluttert M, Ron de Kloet E (1994) The effect of corticosterone on reactivity to spatial novelty is mediated by central mineralocorticosteroid receptors. Eur J Neurosci 6:1072-1079. https ://doi.org/10.1111/j.1460-9568.1994.tb00604.x

Oitzl MS, van Haarst AD, Sutanto W, de Kloet ER (1995) Corticosterone, brain mineralocorticoid receptors (MRs) and the activity of the hypothalamic-pituitary-adrenal (HPA) axis: the Lewis rat as an example of increased central MR capacity and a hyporesponsive HPA axis. Psychoneuroendocrinology 20:655-675. https:// doi.org/10.1016/0306-4530(95)00003-7

Oitzl MS, van Haarst AD, de Kloet ER (1997) Behavioral and neuroendocrine responses controlled by the concerted action of central mineralocorticoid (MRS) and glucocorticoid receptors (GRS). Psychoneuroendocrinology 22(Suppl 1):S87-S93. https://doi. org/10.1016/S0306-4530(97)00020-6

Oitzl MS, Fluttert M, Sutanto W, de Kloet ER (1998) Continuous blockade of brain glucocorticoid receptors facilitates spatial learning and memory in rats. Eur J Neurosci 10:3759-3766. https ://doi.org/10.1046/j.1460-9568.1998.00381.x

Oitzl MS, Reichardt HM, Joëls M, de Kloet ER (2001) Point mutation in the mouse glucocorticoid receptor preventing DNA binding impairs spatial memory. Proc Natl Acad Sci U S A 98:1279012795. https://doi.org/10.1073/pnas.231313998

Oomen CA, Mayer JL, de Kloet ER et al (2007) Brief treatment with the glucocorticoid receptor antagonist mifepristone normalizes the reduction in neurogenesis after chronic stress. Eur J Neurosci 26:3395-3401. https://doi.org/10.1111/j.1460-9568.2007.05972 .x

Picard M, Juster R-P, McEwen BS (2014) Mitochondrial allostatic load puts the 'gluc' back in glucocorticoids. Nat Rev Endocrinol 10:303-310. https://doi.org/10.1038/nrendo.2014.22

Pineau F, Canet G, Desrumaux C et al (2016) New selective glucocorticoid receptor modulators reverse amyloid- $\beta$ peptide-induced hippocampus toxicity. Neurobiol Aging 45:109-122

Ratka A, Sutanto W, De Kloet R (1988) Long-lasting glucocorticoid suppression of opioid-induced antinociception. Neuroendocrinology 48:439-444. https://doi.org/10.1159/000125046

Ratka A, Sutanto W, Bloemers M, de Kloet ER (1989) On the role of brain mineralocorticoid (type I) and glucocorticoid (type II) receptors in neuroendocrine regulation. Neuroendocrinology 50:117-123. https://doi.org/10.1159/000125210

Reichardt HM, Kaestner KH, Tuckermann J et al (1998) DNA binding of the glucocorticoid receptor is not essential for survival. Cell 93:531-541. https://doi.org/10.1016/S0092-8674(00)81183-6

Repunte-Canonigo V, Shin W, Vendruscolo LF et al (2015) Identifying candidate drivers of alcohol dependence-induced excessive drinking by assembly and interrogation of brain-specific regulatory 
networks. Genome Biol 16:68. https://doi.org/10.1186/s1305 9-015-0593-5

Reul JM, de Kloet ER (1985) Two receptor systems for corticosterone in rat brain: microdistribution and differential occupation. Endocrinology 117:2505-2511. https://doi.org/10.1210/ endo-117-6-2505

Reul JM, de Kloet ER, van Sluijs FJ et al (1990) Binding characteristics of mineralocorticoid and glucocorticoid receptors in dog brain and pituitary. Endocrinology 127:907-915. https://doi. org/10.1210/endo-127-2-907

Revsin Y, Rekers NV, Louwe MC et al (2009) Glucocorticoid receptor blockade normalizes hippocampal alterations and cognitive impairment in streptozotocin-induced type 1 diabetes mice. Neuropsychopharmacology 34:747-758. https://doi.org/10.1038/ npp.2008.136

Ronacher K, Hadley K, Avenant C et al (2009) Ligand-selective transactivation and transrepression via the glucocorticoid receptor: Role of cofactor interaction. Mol Cell Endocrinol 299:219-231. https://doi.org/10.1016/j.mce.2008.10.008

Rozeboom AM, Akil H, Seasholtz AF (2007) Mineralocorticoid receptor overexpression in forebrain decreases anxiety-like behavior and alters the stress response in mice. Proc Natl Acad Sci 104:4688-4693. https://doi.org/10.1073/pnas.0606067104

Sapolsky RM, Romero LM, Munck AU (2000) How do glucocorticoids influence stress responses? Integrating permissive, suppressive, stimulatory, and preparative actions. Endocr Rev 21:55-89. https ://doi.org/10.1210/edrv.21.1.0389

Sarrieau A, Dussaillant M, Agid F et al (1986) Autoradiographic localization of glucocorticoid and progesterone binding sites in the human post-mortem brain. J Steroid Biochem 25:717-721. https ://doi.org/10.1016/0022-4731(86)90300-6

Schinkel AH, Wagenaar E, van Deemter L et al (1995) Absence of the mdr1a P-Glycoprotein in mice affects tissue distribution and pharmacokinetics of dexamethasone, digoxin, and cyclosporin A. J Clin Invest 96:1698-1705. https://doi.org/10.1172/JCI118214

Schmidt MV, Sterlemann V, Wagner K et al (2009) Postnatal glucocorticoid excess due to pituitary glucocorticoid receptor deficiency: Differential short- and long-term consequences. Endocrinology 150:2709-2716. https://doi.org/10.1210/en.2008-1211

Schwabe L, Schächinger H, de Kloet ER, Oitzl MS (2010) Corticosteroids operate as a switch between memory systems. J Cogn Neurosci 22:1362-1372. https://doi.org/10.1162/jocn.2009.21278

Schwabe L, Tegenthoff M, Höffken O, Wolf OT (2013) Mineralocorticoid receptor blockade prevents stress-induced modulation of multiple memory systems in the human brain. Biol Psychiatry 74:801-808. https://doi.org/10.1016/j.biopsych.2013.06.001

Solomon MB, Wulsin AC, Rice T et al (2014) The selective glucocorticoid receptor antagonist CORT 108297 decreases neuroendocrine stress responses and immobility in the forced swim test. Horm Behav 65:363-371. https://doi.org/10.1016/j.yhbeh .2014.02.002

Sousa N (2016) The dynamics of the stress neuromatrix. Mol Psychiatry 21:302-312. https://doi.org/10.1038/mp.2015.196

Spencer RL, Kim PJ, Kalman BA, Cole MA (1998) Evidence for mineralocorticoid receptor facilitation of glucocorticoid receptordependent regulation of hypothalamic-pituitary-adrenal axis activity. Endocrinology 139:2718-2726. https://doi.org/10.1210/ en.139.6.2718

Spiga F, Knight DM, Droste SK et al (2011) Differential effect of glucocorticoid receptor antagonists on glucocorticoid receptor nuclear translocation and DNA binding. J Psychopharmacol 25:211-221. https://doi.org/10.1177/0269881109348175

Stranahan AM, Arumugam TV, Cutler RG et al (2008) Diabetes impairs hippocampal function through glucocorticoid-mediated effects on new and mature neurons. Nat Neurosci 11:309-317. https://doi.org/10.1038/nn2055
Teich T, Dunford EC, Porras DP et al (2016) Glucocorticoid antagonism limits adiposity rebound and glucose intolerance in young male rats following the cessation of daily exercise and caloric restriction. Am J Physiol Metab 311:E56-E68. https://doi. org/10.1152/ajpendo.00490.2015

Ulrich-Lai YM, Herman JP (2009) Neural regulation of endocrine and autonomic stress responses. Nat Rev Neurosci 6:397-409. https ://doi.org/10.1038/nrn2647

Thomson F, Craighead M (2008) Innovative approaches for the treatment of depression: targeting the HPA axis. Neurochem Res 33:691-707. https://doi.org/10.1007/s11064-007-9518-3

van Gemert NG, Joëls M (2006) Effect of chronic stress and mifepristone treatment on voltage-dependent $\mathrm{Ca} 2+$ currents in rat hippocampal dentate gyrus. J Neuroendocrinol 18:732-741. https ://doi.org/10.1111/j.1365-2826.2006.01472.x

van Dijk AM, van Wimersma Greidanus TB, Burbach JP et al (1981) Brain adrenocorticotrophin after adrenalectomy and sham-operation of rats. J Endocrinol 88:243-253. https://doi.org/10.1677/ joe. 0.0880243

van Eekelen JAM, Kiss JZ, Westphal HM, de Kloet ER (1987) Immunocytochemical study on the intracellular localization of the type 2 glucocorticoid receptor in the rat brain. Brain Res 436:120 128. https://doi.org/10.1016/0006-8993(87)91563-0

Van Haarst AD, Oitzl MS, Workel JO, De Kloet ER (1996) Chronic brain glucocorticoid receptor blockade enhances the rise in circadian and stress-induced pituitary-adrenal activity. Endocrinology 137:4935-4943. https://doi.org/10.1210/en.137.11.4935

van Haarst AD, Oitzl MS, de Kloet ER (1997) Facilitation of feedback inhibition through blockade of glucocorticoid receptors in the hippocampus. Neurochem Res 22:1323-1328. https://doi. org/10.1023/A:1022010904600

Van Weert LTCM, Buurstede JC, Mahfouz A et al (2017) NeuroD factors discriminate mineralocorticoid from glucocorticoid receptor DNA binding in the male rat brain. Endocrinology 158:15111522. https://doi.org/10.1210/en.2016-1422

van den Heuvel JK, Boon MR, van Hengel I et al (2016) Identification of a selective glucocorticoid receptor modulator that prevents both diet-induced obesity and inflammation. Br J Pharmacol 173:1793-1804. https://doi.org/10.1111/bph.13477

van der Hoeven RA, Hofte AJ, Frenay M et al (1997) Liquid chromatography-mass spectrometry with on-line solid-phase extraction by a restricted-access $\mathrm{C} 18$ precolumn for direct plasma and urine injection. J Chromatogr A 762:193-200. https://doi.org/10.1016/ S0021-9673(96)01004-7

van der Veen R, Boshuizen MCS, de Kloet ER (2013) Mifepristone treatment affects the response to repeated amphetamine injections, but does not attenuate the expression of sensitization. Psychopharmacology 230:547-556. https://doi.org/10.1007/s0021 3-013-3176-8

Vendruscolo LF, Barbier E, Schlosburg JE et al (2012) Corticosteroiddependent plasticity mediates compulsive alcohol drinking in rats. J Neurosci 32:7563-7571. https://doi.org/10.1523/JNEUR OSCI.0069-12.2012

Vendruscolo LF, Estey D, Goodell V et al (2015) Glucocorticoid receptor antagonism decreases alcohol seeking in alcoholdependent individuals. J Clin Invest 125:3193-3197. https://doi. org/10.1172/JCI79828

Wulsin AC, Herman JP, Solomon MB (2010) Mifepristone decreases depression-like behavior and modulates neuroendocrine and central hypothalamic-pituitary-adrenocortical axis responsiveness to stress. Psychoneuroendocrinology 35:1100-1112. https://doi. org/10.1016/j.psyneuen.2010.01.011

Young EA, Lopez JF, Murphy-Weinberg V et al (1998) The role of mineralocorticoid receptors in hypothalamic-pituitary-adrenal axis regulation in humans 1. J Clin Endocrinol Metab 83:33393345. https://doi.org/10.1210/jcem.83.9.5077 
Zalachoras I, Houtman R, Atucha E et al (2013) Differential targeting of brain stress circuits with a selective glucocorticoid receptor modulator. Proc Natl Acad Sci USA 110:7910-7915. https://doi. org/10.1073/pnas.1219411110
Zalachoras I, Verhoeve SL, Toonen LJ et al (2016) Isoform switching of steroid receptor co-activator-1 attenuates glucocorticoidinduced anxiogenic amygdala CRH expression. Mol Psychiatr 21:1733-1739. https://doi.org/10.1038/mp.2016.16 